Mirko Vladisavljević

Lucern, Švajcarska

vladisavljevic@gmx.ch

DOI: 10.18485/rit.2021.19.36.2
UDK: 615.85:638.16

613.86

Origanalni naučni rad

Datum prijema: 04.05.2021

\title{
STRES I STRAH U USLOVIMA SAVREMENE PANDEMIJE
}

\begin{abstract}
Rezime
Strahovi i stres su čvor naših misli koji treba razvezati. Kada u tome uspemo stres $i$ strah postaju pokretačka sila života motivisana nebrojenim pojavama života, mnogobrojnim mogućnostima novih životnih ciljeva u okvirima granica nebeske ljubavi. Savršena ljubav Hristova ,, izgoni strah napolje“ i omogućava nam slobodu od svih zavisnosti. Zavisnosti gospodare bićem preko straha, ukidanjem slobode razmišljanja $i$ slobode egzistencije, podređivanjem individue grupi kojom vlada sila straha, agresije i hijerarhija potčinjenosti jačem. Agresija je stalno aktivna jer konstantno dokazuje da je u pravu, traženjem krivca radi ostvarivanja neke lične dominacije. Potpunim upoznavanjem Hrista, potpune večne istine i beskrajne sile nebeske ljubavi, postajemo deo grupe slobodnih od straha i slobodnih od verbalne, neverbalne, paraverbalne i fizičke agresije. Hristos je pokretačka i stvaralačka sila ljubavi nebrojenih pojava života u nama i oko nas. Sa Njim možemo uspešno ostvariti „,reset“ "naših misli i postići toliko neophodnu opuštenost u vremenu savremene pandemije.
\end{abstract} opuštenost

Ključne reči: stres, strah, zavisnost, agresija, grupa, Hristos, ljubav, život,

\section{Uvod}

U uslovima savremene pandemije strahovi i stres dobijaju na intenzitetu. Ovaj rad će pokušati da predstavi jedan dobar uvid u problematiku strahova $\mathrm{i}$ stresa na osnovu dostupnih teorijskih i praktičnih iskustava. Strahovi i stres su čvor naših misli koji treba razvezati. Kada u tome uspemo stres i strah postaju pokretačka sila života i mnogobrojnim mogućnostima novih životnih ciljeva. Zavisnosti gospodare bićem putem straha, ukidanjem slobode razmišljanja i egzistencije, podređivanjem individue grupi kojom vlada sila straha, agresije i hijerarhija potčinjenosti jačem. Agresija je stalno aktivna jer konstantno dokazuje da je u pravu, traženjem krivca radi ostvarivanja neke lične dominacije. Potpunim upoznavanjem Hrista, potpune večne istine i beskrajne sile nebeske ljubavi, postajemo deo grupe slobodnih od straha i slobodnih od verbalne, neverbal- 
ne, paraverbalne i fizičke agresije. Hristos je pokretačka i stvaralačka sila ljubavi nebrojenih pojava života u nama i oko nas. Sa Njim možemo uspešno ostvariti „reset“ naših misli i postići toliko neophodnu opuštenost u uslovima savremene pandemije.

\section{STRES}

Razmišljanja da je stres prisutan svuda oko nas, da osećamo napetost i potrebu za odmorom, kao i potrebu da se bar na kratko isključimo iz svega toga je naša svakodnevica. (Pörner, 7)

„Stres je instiktivna reakcija na akutnu opasnost. Spoljašnji ili unutrašnji receptori stresa pozivaju na jednu, kao munja brzu reakciju stresa, koja se pokazuje telesno, emocionalno i mentalno u našim stavovima, a služi preživljavanju“ (Pörner, 18).

Sigmund Frojd, zaključuje da postoje realani strahovi. Reakcija na realan strah može biti „,bežanje“ ili ,afekt“. Bez obzira u kakvim okolnostima i zbog kakvih objekata nastupa opasnost i strah, refleksna reakcija bežanja je unutrašnje ispoljavanje samozaštite, smatra Frojd (Freud, 376-378).

Frojdov realan strah je prihvaćen u psihologiji, a definisan je kao stres. Reakcije na realan strah tj. stres, „,bežanje“ i ,,afekt", pojavljuju se u novijoj literaturi kao „bežanje“ i „borba“ (Pörner, 17-22).

Pojam stres je preuzet iz Latinskog jezika, a potiče od reči „stingere“ što podrazumeva napetost, napon ili zategnutost (Pörner, 17), kao na primer žica na gitari.

„Stres nije neka velika loša pojedinost kako je svi zamišljaju - zapravo, većina akutnih stresora podstiču rad imunog sistema“ naglasio je dr Boš. „Samo kada se stres neuobičajeno produžava, ili se stalno ponavlja, on postaje potencijalna pretnja zdravlju“ (Nidli, 133-134).

Mnogobrojni ljudi rastrzani između obaveza i izazova, rascepljeni između obaveza na poslu i porodičnih odnosa, uopšte se ne snalaze. Već godinama, u izveštajima zdravstva u Švajcarskoj, imamo porast broja onih koji pate od Burn - out sindroma, anksioznosti i depresije. Telo i psiha kao da neverbalno žele da nam kažu da to tako dalje ne ide (Pörner, 9).

Ono što je nama neophodno potrebno je da izgradimo snažnu protivtežu stresu, strahu i napetosti koji nas svakodnevno pritiskaju. Neophodno je izgraditi poverenje u sebe i unutrašnju snagu, kojom ćemo uspešno savladavati izazove i nagle promene u životu, što će nam omogućiti da uvek budemo u aktivnoj ravnoteži (Pörner, 10-12). 


\section{Uzroci stresa}

Među najveće uzročnike stresa, ubraja se život u velikim gradovima. Ono što velike gradove čini tako stresnim je neprirodna velika buka i zagađenje vazduha. Veliki uzročnik stresa može biti i lično zdravstveno stanje, operacija, bolest ili smrt bliske osobe, lični problemi i brige, konflikti u porodičnim odnosima, usamljenost, novo radno mesto, novi poslovođa, nezadovoljstvo radnim mestom, loši međuljudski odnosi u timu na poslu, izostavljanje pohvale za zalaganje radnika, konkurencija u timu i još mnogo toga (Pörner, 20).

Dobro je primetiti da stres majke tokom trudnoće i ranom detinjstvu deteta, može ostaviti posledice na dete u njegovom daljem životu (Pörner, 21).

Kada se dobro najedemo loše hrane, počinje varenje i stvaranje velike količine šećera. Povišena količina šećera u krvi, alarmira hormon insulin, koji odmah kreće u akciju skladištenja šećera u jetru i mišiće. Kada insulin završi svoj posao, vrednosti šećera u krvotoku padaju ispod potrebnog minimuma. Satima posle jela, pored osećaja sitosti, osećamo se nemirno, nervozno, razdražljivo, umorno i depresivno. Bolesti štitne žlezde usporavaju reakcije insulina, koji je bio previše vredan, pa je uklanjanjem šećera u mišiće i jetru odneo prevelike količine šećera, pa ga zbog toga štitna žlezda sada kažnjava i usporava u radu (Panagos, 30-31).

Dakle, lošom ishranom uzrokujemo rat između štitne žlezde i insulina, jednog od najvažnijih hormona u našem organizmu. U borbu se odmah uključuje kortizol, još jedan iz grupe najvažnijih hormona, da bi očuvao ravnotežu šećera u krvi, pa tako slabi naš imuni sistem i uzrokuje mnogobrojne zdravstvene probleme (Panagos, 26-27). Zato, ne treba da nas čudi da se često osećamo loše, umorno i napeto, jer smo lošom ishranom prouzrokovali hormonalnu neravnotežu u vlastitom organizmu i tako pokrenuli lavinu zdravstvenih problema, kojima prethodi pojava stresa.

\section{Reakcije na stres}

Nervni sistem simpatikusa biva u hitnim intervencijama aktiviran, pa nas pokreće na „borbu“ ili „bežanje“. Ovakve reakcije zahtevaju velike količine energije tela. Telo reaguje povišenim krvnim pritiskom, srce ubrzanim pulsom, pluća pojačanim disanjem, sve sa razlogom da se mozgu i mišićima obezbedi dodatna hrana i snaga. Vrednosti šećera rastu, a mi smo u stanju pripravnosti, koncentrisani i spremni za akciju. Sve druge potrebe organizma, bivaju privremeno obustavljene. 
Nervni sistem parasimpatikusa se aktivira nezavisno od hitnih intervencija i omogućava nam da se umirimo, odmorimo i svarimo posledice napete situacije te hitne intervencije. Dakle, parasimpatikus se angažuje na reparaciji nastalih oštećenja, povodom nedavnog vanrednog stanja organizma. Zato uzrokuje pospanost $\mathrm{i}$ opuštanje tela, podupire varenje i oslobađanje toksina iz organizma (Panagos, 44).

Nakon vrlo stresnih situacija, treba obezbediti vreme za opuštanje i odmor kada se povrede od stresa rehabilituju, a organizam dobije mogućnost da „napuni baterije“. U ovom procesu aktivni su Simpatikus i Parasimpatikus, od kojih zavisi naš rast, regenerativni procesi pa čak i naše uzimanje hrane u organizam. Za regeneraciju i ponovno uspostavljanje ravnoteže u organizmu potrebne su pauze, opušteno vreme bez stresa. Nažalost, u današnje vreme po nekoliko puta dnevno ulazimo u stresne situacije, što nas ukoliko se nastavi danima, dovede do hroničnog stresa. Utisak je da živimo u društvu koje je konstantno željno novog adrenalina i napetosti, spremno da na znak sirene za uzbunu pojuri u novu stresnu avanturu (Pörner, 22).

\section{Telesni stres}

Telesne reakcije na stres ispoljavaju se lupanjem srca, karakteristikom ubrzanog disanja i povišenim krvnim pritiskom. Osoba oseća unutrašnji nemir, vrućinu, vruće obraze, znojave dlanove i napregnute mišiće (Pörner, 23).

\section{Mentalni stres}

Ovakav stres pričinjava poteškoće osobama da se koncentrišu na neku aktivnost i ne mogu da istraju do kraja pa odustanu. Mentalni stres može dugo da potraje ili je trajan, često dolazi do senilnosti i problema sa zaboravljanjem reči, kojih se ljudi sa ovim stresom, ne mogu setiti. Takve osobe, sklone su kritikovanju sebe, gube motivaciju i smisao postojanja (Pörner, 24).

\section{Emocionalni stres}

Ovaj vid stresa karakteriše strah kod osoba da „neće uspeti ili postići“ da budu pohvaljeni, voljeni ili prepoznati na bilo koji način. Slabo kontrolišu svoje emocije, a mogu da dožive i napad panike. Takođe, mogu da reaguju depresivno, bezvoljno, sa gubitkom motivacije, distanciranjem od svih aktivnosti. Osećaju se kao žrtve, uzimaju stvari lično i smatraju sebe napadnutim (Pörner, 24-25). 


\section{Hronični stres}

Povlači osobe da u velikim količinama uzimaju hranu, konzumiraju alkohol ili duvan (lake droge), lekove za smirenje, ili uzimaju jake droge. Pored toga mogu da budu zavisni od kompjutera, interneta, televizora, svakodnevne kupovine nepotrebnih stvari, na primer garderobe. Ovakve osobe su konstantno u nekoj akciji, ne mogu ni jedan minut mirno da sede, izrabljuju sebe bez pauze, brzo eksplodiraju i sklone su da se povuku u sebe. Hronični dugoročni stres je u stanju da naruši zdravlje (Pörner, 25-31).

\section{Traumatski stres}

Ovo je stres koji obuhvata: velike životne krize, prirodne katastrofe, saobraćajne nesreće, zlostavljanja, mobing, gubitke najbližih dragih osoba, kao i operacije i bolesti u porodici. Pošto u ovakvim situacijama ne pomaže ni opcija ,pobeći“, ni opcija „boriti se“ sa problemom, organizam se podsvesno odlučuje za opciju „mrtav sam“ i parališe celo telo u stanje ukočenosti. U ovakvom stanju telesne aktivnosti se svode na minimum, a šanse za preživljavanjem naglo rastu. Kao posledica trauma mogu se pojaviti traumatski snovi. Ogromnu količinu energije stresa, usled posledica traume, nije moguće u potpunosti isprazniti iz organizma, pa ona ostaje prisutna u nervnom sistemu u nekoj meri. Kao posledice, nastaju tipični simptomi stresa: emocionalna preosetljivost, hiper aktivnost, hiper uznemirenost, napadi panike, depresija i osećaj otuđenosti (Pörner, 29).

\section{Opuštenost je rešenje}

U Antičkoj Grčkoj postojao je pojam ,stoički miran“, koji je podrazumevao da čovek u sebi mora da zadržava i nikada ne ispoljava svoje probleme, patnje i emocije, da bi na taj način za sebe obezbedio bolje mesto u društvu (Pörner, 34).

\section{Treba otpustiti i pustiti}

Stoički mudraci nisu pronašli put do opuštenog načina života, jer nisu znali poslovicu koja nam nudi dobar recept u prevazilaženju stresa: „Ako hoćeš da budeš opušten, onda moraš da pustiš “. Dokle god nismo sigurni gde i zbog čega smo zategnuti nismo u stanju ni da pustimo, ni da otpustimo. Pre nego pustimo moramo pouzdano znati čega se to u stvari čvrsto držimo. Onaj ko pušta omogućava 
stabilnu slobodu i sebi i drugima, a kao posledicu doživljava opuštenost. Kontinuiranim puštanjem otvara se prostor za jačanje poverenja, što omogućava da naša opuštenost raste. Puštanje nam uzima mnogo energije, ali takođe otvara nove prostore u nama, pa tako nastaju nove šanse i mogućnosti. Važno je pronaći šta je to što je u vlastitom životu stvarno važno (Pörner, 34-37).

\section{Treba oprostiti sebi i drugima}

Doktor medicine, psihijatar i psihoterapeut, Martin Grabe, smatra da opuštenost ne može doći u naš život bez praštanja. Njegova definicija praštanja glasi: „Uvodim novo stanje ravnoteže i prihvatam izmenjenu sliku o sebi, koja odgovara mojoj sadašnjosti“. Osoba koja uz pomoć praštanja ostvori unutrašnju ravnotežu, uspelo joj je da zaseče u sistem ličnih vrednosti. Od sada postoje stvari i područja koja ona više ne doživljava toliko lično kao ranije“" (Grabe, 142).

On dodaje: „Putevi praštanja vode novoj ravnoteži, a ostvarena je tek tada, kada povređena osoba izrazi spremnost da živi sa štetom novonastalog stanja. Dokle god se sve u njoj protivi nepravdi doživljenih rezova i ograničenja, neće imati mira. Zadovoljstvo nastaje tek tada, kada jedna osoba svoje uspehe, i sreću svog života, meri prema mogućnostima koje joj sada stoje na raspolaganju. Nikako ne na onim mogućnostima koje je nekada imala, ili je mislila da ih ima. Nije lako prihvatiti da mi ožiljci vlastitog života pripadaju, ne odbijajući ih više kao strano telo. Ali, ukoliko prihvatanje uspe, ono često otvara neočekivane nove mogućnosti, koje su nastale iz neponovljivosti mog novonastalog bića“ (Grabe, 142).

\section{Treba doneti odluku i menjati vlastite loše navike}

Psiholog Gabi Perner kaže: „Čovek je životinja svojih navika“ (Pörner, 65). Pretpostavljam da je autor ovom rečenicom želela da kaže, da čovek svoje navike može svesti na najosnovnije životne funkcije, koje i životinja poseduje i upražnjava. U poređenju sa našom narodnom izrekom da je čovek rob svojih navika, nazire se razlika. Ukoliko je čovek rob on je prinuđen, protiv svoje volje, da čini ono što njegov gospodar zahteva. Naravno, postoji još jedna mogućnost; da čovek samostalno donosi odluke da bude ,životinja“, ili nešto više od toga i počne da izgrađuje sebe.

Ruski mislilac Nikolaj Berđajev, u svojoj knjizi „O čovekovom ropstvu i slobodi“, govori o robovima, gospodarima i slobodnima. Problem robova i go- 
spodara je u tome što oni uvek postoje u korelaciji, jer ne mogu jedni bez drugih. Bez tog zavisnog odnosa, kao da se plaše da njihova egzistencija, više neće postojati. Upravo je uklanjanje ove korelacije veoma potrebno, smatra Berđajev, da bi čovek doživeo svoju pravu slobodu. Slobodni, kako ih on naziva, nemaju potrebu niti da robuju nekome ili nečemu, niti da gospodare nad nekim ili nečim. Zato on favorizuje slobodne i navodi Isusa Hrista kao najbolji primer, jer je slobodan od sveta, od svih zavisnosti, pa zato zrači opuštenost i mir (Berđajev, 126-127). Ukoliko čovek želi da živi opušteno, mora da iskorači iz svojih pomalo problematičnih navika, koje se godinama gomilaju i talože, a koje ga čine napetim, zategnutim i podložnim stresu. Psiholog Perner navodi tri pitanja koja uvek iznova treba sebi da postavljamo:

- Šta nas sputava da činimo upravo ono što želimo?

- Zašto se vraćamo u staru kolotečinu, iako smo sve preduzeli da se tamo više ne vraćamo?

- Zašto uvek iznova odlažemo za sutra, ono sa čime smo odavno želeli da završimo?

Zato, Perner smatra, svaka osoba treba da preispita svoje navike i običaje da bi uvidela šta je to što treba menjati, a šta je beskorisno i stresno u vlasitom životu, što zasigurno treba izostaviti, da bismo konačno počeli da živimo opušten život bez stresa (Pörner, 65-83).

Na prvo, od tri postavljena pitanja sebi, apostol Pavle daje dobar odgovor $\mathrm{u}$ Svetom pismu: „Sve mi je slobodno, ali mi nije sve na korist; sve mi je slobodno, ali neću da šta ovlada mnome“ (Biblija, Sveto pismo, Prva poslanica Korinćanima 6, 12). Drugim rečima, mogu smatrati da mi je sve slobodno, ali nikako ne želim da postanem ,životinja“" svojih navika, jer takvo stanje ima jasne konture zavisnosti i šteti mom zdravlju.

Kao odgovor na drugo i treće pitanje, koja nam psiholog Perner predlaže da svakodnevno postavljamo sebi, kao da nas već ona sama navodi na odgovor. Ukoliko sam i dalje ,životinja“" svojih navika, onda se vraćam u staru kolotečinu i uvek iznova odlažem da odlučno iskoračim sa potrebnim promenama $u$ svom životu.

\section{Treba postići ravnotežu između emocionalnog i racionalnog rasuđivanja}

Doktor Nil Nidli nam predlaže šta treba raditi kada emocije i emocionalna razmišljanja počnu snažno da naviru. Njegov predlog je da vežbamo sebe u kontroli misli i naučimo sebe da se krećemo u pravcu racionalnih odluka: 
„Gubitak posla, tinejdžerska trudnoća ili automobil kome je potrebna popravka - sve su to praktični problemi, s druge strane, su neprijatna osećanja doživljena zbog praktičnih problema. Na primer, možete osećati krivicu u vezi sa gubitkom posla, stid što vaša ćerka očekuje bebu mimo braka, ili ste pod stresom što vam se auto pokvario. S obzirom da emocionalni odgovori na praktične probleme mogu biti tako intenzivni, važno je prvo razrešiti emocionalne prepreke, pre nego što razrešimo praktične probleme kadgod je to moguće. Da biste ovo uradili, morate najpre da prepoznate vrstu problema sa kojim se suočavate. Zatim možete međusobno da zavadite emocionalne i praktične probleme, pa da njima zavladate, da tako kažem" (Nidli, 135).

Ključ emotivnog rasuđivanja je u proveravanju postojećih pretpostavki, bez davanja mogućnosti našim emocijama da zavladaju našim bićem. U našem rasuđivanju i odlučivanju su potrebni i razum i emocije. Bez prisustva osećanja odluke su tako bezlične i nedostaje im motivacija. Zato se često događa da strast pali vatru naše inicijative. Kada odluke donosimo na osnovu osećanja, pratiće ih kratkovide akcije i impulsivnost. Rešenje je naći pravu ravnotežu između emocionalnih i racionalnih misli, istovremeno gledajući kakav će uticaj naše odluke imati na našu budućnost $\mathrm{i}$ budućnost drugih.

Doktor Nidli navodi da je rešenje u postizanju ravnoteže između emocionalnog i racionalnog rasuđivanja bez osvrtanja na trenutna osećanja: „Kada donosite odluku, razmišljajte analitički i bićete u stanju da se oslobodite procesa robovanja svojim emocionalnim razmišljanjima, koja vas drže u okovima nepoželjnog Životnog stila“ (Nidli, 135-137).

\section{MOĆ HORMONA I TOKSINI}

Stres nastaje kada nervni sistem sklizne iz ravnoteže. Tada se preko autonomnog nervnog sistema, nezavisnog od naših odluka, aktivira Simpatikus, pa se pomoću hormona adrenalina, noradrenalina i kortizola aktiviraju fiziološki procesi, koji nas maksimalno razbude i spreme za najzahtevnije zadatke. Drugim rečima, naš organizam se uključi u ,turbo“ modus. Zahvaljujući ovom stanju, jedan deo velikog mozga biva blokiran, jer svako drugo razmišljanje osim onog o preživljavanju nije potrebno u datom trenutku. Apetit i druga čulna zadovoljstva, potpuno se isključe. U sistem ljudskog organizma ugrađena su tri „tastera“, od kojih se samo jedan aktivira u ovakvoj, stresnoj situaciji: „borba“ protiv opasnosti, „bežanje“ od opasnosti, ili taster „mrtav sam“, koji isključuje mogućnost borbe ili bežanja. Totalna ukočenost u stanju „mrtav sam“, potraje dok opasnost ne pro- 
đe u potpunosti (Pörner, 22). Ostaje pitanje kako da uverimo svoj organizam da je opasnost prošla; da modus ,turbo“ treba isključiti i veliki mozak ponovo uključiti da radi i razmišlja?!

Ako bismo bili iskreni prema sebi, shvatili bismo da smo često uznemireni i umorni, pod stresom i osećamo se loše. Ukoliko smo već duže vremena izloženi stresu i umoru, zaboravljamo često kako bismo dobro mogli da se osećamo. To se događa zato što smo prestali da osluškujemo naše telo i naš organizam. Umesto toga uzimamo stimulaciju u vidu šećera, gotovih prerađenih namirnica i kofeina. Cena otuđenja od vlastitog tela je da u nama nametnutoj brzini života postajemo letargični i osećamo da smo izgurani iz vlastite ravnoteže (Panagos, 9-10).

Kao nikada do sada smo zasuti mnogobrojnim štetnim hemikalijama teških metala koji su prisutni u sredstvima za čišćenje, lekovima, izduvnim gasovima, otpadnim produktima proizvodnje, posuđu za namirnice, svećama, osveživačima vazduha i mnogobrojnim drugim materijalima. Jetra je jedan od najvažnijih organa koji ima ulogu odstranjivanja opasnih i štetnih materija iz organizma, a da pri tome ne dođe do oštećenja ćelija organizma ili Hormona. Novija otkrića ukazuju na činjenicu da toksini često imaju posebno loš uticaj na žlezde sa unutrašnjim lučenjem. Toksini na veštački način utiču na hormonalnu sliku i doprinose potpunoj razgradnji hormona u organizmu (Panagos, 38-39).

\section{Hormoni}

Panagos navodi sledeće simptome hormonalne neravnoteže u organizmu. To su: nesanica, zatvor, vetrovi, osip kože, bubuljice, umor, slab koren kose, sklonost ka gojaznosti, strahovi, glavobolje, migrene, PMS, zaboravnost, depresija, tuga, razdražljivost, sklonost ka stresu, tmurno raspoloženje, promenljivo raspoloženje, velika glad, masna kosa, hladne ruke i stopala (Panagos, 10).

Mnogobrojni hormoni deluju u našem organizmu. Fokusiraćemo se samo na one najvažnije: progesteron, testosteron, ostrogen, kortizol, hormone štitne žlezde i insulin. Mnogi se odlučuju na dijete bez uzimanja masnoća u organizmu, što nije ispravno. Našem organizmu su potrebne izvesne količine masnih kiselina, tačnije lipida, za uravnotežen rad naših hormona. Bez esencijalnih masnih kiselina, naš organizam nije u stanju da obezbedi dovoljnu količinu ostrogena, progesterona i testosterona. Manjkanje ovih hormona u organizmu, oslikaće se nesigurnošću, pospanošću i u nedostatku životne energije (Panagos, 17). 


\section{Progesteron}

Ovaj hormon ima pozitivno delovanje za izgradnju kostiju, izgradnju ravnoteže ostrogena, zdravlje srca i krvotoka, zdravlje nervnog sistema, zdravlje moždanih funkcija i uravnoteženo raspoloženje, kao i na sprečavnje nesanice (Panagos, 20).

Razlog za hormonalnu neravnotežu u organizmu nije jedino stres. Mada u velikoj meri, na rad hormona progesterona utiče hronični stres. Drugi faktori neravnoteže mogu biti: genetski faktori, starost organizma, oslabljen rad štitne žlezde, zatim nedostatak vitamina i minerala (kao npr. magnezijum, vitamin A, vitamin B6, C vitamin, cink), smetnji u ishrani, hrana oskudna vitaminima i mineralima može takođe biti jedan od razloga, kao i velika količina šećera u ishrani (slatkiši). Posledice neuravnoteženog progesterona u organizmu, mogu biti pobačaji trudnoće, osteoporoza, razdražljivost, napadi strahova i nesanica (Panagos, 20-21).

\section{Testosteron}

Ovaj hormon potpomaže: vitalnost, raspoloženje, memoriju pamćenja, jačanje vezivnih tkiva, jačanje kostiju i mišićne mase, moždane funkcije, istrajnost osobe, samopoverenje i zadovoljstvo.

Pojava prevelike količine testosterona u organizmu je reakcija na visoku količinu insulina. Ovaj problem nastaje najčešće konzumiranjem velike količine šećera i gotovih prerađenih namirnica (Fast food).

Razlog premale količine testosterona u organizmu je najčešće stres. Stres pokreće pojavu hormona kortizola i pregnenola i tako redukuje količine izlaznih materija koje treba da vezuju testosteron.

Neravnoteža testosterona $u$ organizmu manifestuje se: masnom kožom, bubuljicama, prekomernom rastu kose i dlačica po telu, umorom, napadima straha, depresijom, porastom telesne mase. Takođe, manifestuje se i opadanjem kose kod muškaraca i neredovnim ciklusima kod žena (Panagos, 22-23).

\section{Ostrogen}

Ovaj hormon obavlja više od tristotine funkcija u organizmu. Najvažnije su: izgradnja gustih kostiju i snažne mišićne mase, ima uticaj na naše raspoloženje održavanjem izgradnje serotonima (neurotransmiter), funkcija zaštite kože, srca i 
arterija, održava koncentraciju i logično razmišljanje, pojačava lučenje magnezijuma iz hrane i poboljšava sliku insulina.

Povišeni stres, toksini urbane sredine, alkohol i kofein, mogu značajno povisiti vrednosti ostrogena u organizmu. Nasuprot tome, niske vrednosti ostrogena vode poreklo od: uzimanja antibebi pilula, hemoterapije, zračenja, i drugih medicinskih zahvata u lečenju karcinoma, kao i od pojave genetskih bolesti, anoreksije i problema štitne žlezde.

Neravnoteža ostrogena u organizmu, ispoljava se: neuravnoteženim raspoloženjem, gubitkom pamćenja, fokusiranjem na probleme, razdražljivošću, umorom, naletima vrućine u telu, kao i noćnim preznojavanjem, zatim stresom, napadima straha, proređivanjem koštane strukture, depresijom, PMS-om, gojaznošću (Panagos, 24-25).

\section{Kortizol}

Ovaj hormon takođe ima mnogobrojne važne funkcije u organizmu. Najvažnije uloge ima u: uravnotežavanju šećera u krvi, regulaciji telesne težine, jačanju imunog sistema, kontroli reakcija na stres, omogućavanju kvalitetnog sna i popravljanju raspoloženja.

Kortizol je nezamenljiv u našem životu, jer se stara da ujuto ustanemo i uz pomoć reakcija stresa „borbe ili bežanja“, prebrodimo opasnosti. Neravnoteža kortizola u organizmu ogleda se u: oslabljenom imunom sistemu, pojavi osteoporoze, povišenom krvnom pritisku, povišenom holesterolu u krvi, poremećaju regulacije šećera u krvi. Takođe, ogleda se u umoru, nesanici, razdražljivosti i napadima straha (Panagos, 26-27).

Ukoliko imamo poremećaje sna, ukoliko značajan deo vremena provodimo sa našim mobilnim telefonom, tabletom, naročito u kasnim noćnim satima, nova saznanja potvrđuju da upravo ovi aparati svojom plavom svetlošću urušavaju naš bioritam i hormonalnu ravnotežu. Tome možemo dodati da sve manje vremena provodimo na dnevnom svetlu i sunčevoj svetlosti. Ukoliko želimo da očuvamo naš bioritam, kao i hormonalnu ravnotežu, neophodno je da planiramo svakodnevno izlaganje dnevnom svetlu i sunčevoj svetlosti, izlaskom u prirodu (Panagos, 27).

\section{Hormoni štitne žlezde}

Ovi hormoni stimulišu vezivanje vitamina i minerala iz hrane. Oni utiču na rast, jačaju koren kose, jačaju energiju, regulišu telesnu temperaturu, podržavaju 
ravnotežu idealne telesne težine, utiču na razvoj mozga, nivo holesterola u krvi, varenje, pamćenje, koncentraciju i nivo šećera u krvi.

Neuravnoteženi hormoni štitne žlezde ogledaju se: u porastu telesne mase, ekstremnom osećaju umora, proređivanju i opadanju kose, u hladnim šakama i stopalima, sveobuhvatnom osećaju hladnoće, zatvoru, povišenim vrednostima holesterola u krvi, neredovnim ciklusima i pobačajima kod žena, konstantnoj pospanosti, visokim vrednostima šećera u krvi (Panagos, 28-29).

\section{Insulin}

Ukoliko jedemo slatku ili rafinisanu hranu, punu ugljenih hidrata, varenjem se oslobađa velika količina glukoze. Pošto našim ćelijama nije potrebna toliko velika količina glukoze, insulin transportuje sav ,višak“ u našu jetru i mišiće, gde bivaju privremeno uskladišteni. Bez insulina, organizam ne bi mogao da reguliše velike viškove šećera sa kojima raspolaže.

Potrebe za reakcijama insulina u organizmu, nastaju zbog: rafinisane hrane koja obiluje ugljenim hidratima i šećerom, zatim zbog hrane i pića koji sadrže kofein kao stimulator, stresa, izostavljanja obroka, gojaznosti, hormonalnih problema, životnog stila ispunjenog sedenjem i neaktivnošću, zatim zbog uticaja urbanih toksičnih materija, zbog nesanice, pušenja, neuravnoteženog rada endokrinih žlezda, upala (Panagos, 30).

\section{TOKSINI}

Najveći uzročnici stresa su velika buka, zagađenja vazduha i toksini koji su svakodnevno prisutni, posebno u velikim gradovima (Pörner, 20).

\section{Ksenoostrogeni}

Neverovatno je da su ove supstancije dobile svoje mesto: u proizvodnji plastičnih posuda za namirnice, u metalnim posudama za namirnice, bojama, igračkama, sredstvima za pranje posuđa i veša, bojama i u proizvodnji kozmetike.

Ksenoostrogeni initiraju hormon ostrogen, tako da se naše telo obraduje, prihvati kopiju hormona i uvede razbojnika u masna tkiva, gde hormon ostrogen ima svoju važnu ulogu.

Ksenoostrogen je odgovoran za preuranjeni pubertet kod devojčica, starosti od osam godina i poznat je izazivač raka, posebno raka dojke (Panagos, 40). 


\section{Parabeni}

Parabeni su prisutni u sredstvima za ličnu higijenu, losionima za telo, kremama za kožu i sličnim proizvodima. Nažalost, parabeni su takođe ostrogeni koji se dovode u vezu sa rakom dojke (Panagos, 40).

\section{Ptalati}

Ptalati se nalaze u mekim savitljivim plastičnim predmetima i PVC materijalima. Nalaze se takođe u parfemima, laku za nokte, šamponima, sapunima, spreju za kosu, a koriste se i u proizvodnji sedišta i sve druge opreme za unutrašnjost automobila.

Ova hemikalija povezuje različite supstancije unutar plastike, ali snažno utiče i na hormonalni sistem. Dovodi naše hormone u disbalans, tako što forsira testosteron, a obustavlja rad ostrogena.

Ptalati uzrokuju neplodnost, prekomernu telesnu težinu, rak, dijabetes tip-2, razne alergije i astmu (Panagos, 40).

\section{Bispenol-A (BPA)}

Ovo je jedna hemikalija koja je pronašla svoje mesto u proizvodnji plastičnih flaša, unutrašnjem oblaganju konzervi namirnica, posuđu koje je predviđeno za korišćenje u mikrotalasnoj pećnici. BPA ima sposobnost da se $\mathrm{u}$ toku vremena izdvaja, tj. oslobađa iz plastike.

BPA je ksenohormon koji usporava rad štitne žlezde, dok je potpuno ne zaustavi u radu. Utiče na pojavu raka, neplodnosti, kao i na pojavu prekomerne telesne težine.

Na sreću, već određeni broj godina postoje mnogobrojni proizvodi koji ne sadrže ovu BPA hemikaliju, jer je zabranjena u proizvodnji plastike koja se koristi za namirnice (Panagos, 40).

\section{Dioksini}

Dioksini, POP, ostavljaju doživotna oštećenja ljudskih organa iza sebe. Svoju primenu imaju od proizvodnje PVC materijala pa sve do proizvodnje pesticida. U današnje vreme, POP dioksini, lako ulaze u naš lanac ishrane. Često ih uzimamo nataložene u mesu, mlečnim proizvodima i ribi. Razlog je taj, što se ovi dioksini koriste za masovnu proizvodnju hrane. 
Ovi dioksini utiču na disfunkcije endokrilnih žlezda u našem organizmu. Dioksini POP utiču na neplodnost, stvaraju probleme u razvoju kod dece i oštećuju imuni sistem (Panagos, 41).

\section{NEUTRALISANJE STRESA}

\section{Teorijska i lična iskustva}

Stres je sasvim prirodna reakcija našeg organizma, pa ne treba očekivati da živimo život bez stresa. Istraživanja pokazuju da većina stresora podstiču rad imunog sistema i samim tim jačaju imuni sistem. Naravno, ukoliko se stres često događa ili potraje duže vreme, bez ikakve naše akcije da bilo šta promenimo na bolje, on može postati ozbiljna pretnja našem zdravlju (Nidli, 133-134). Potrebno je da izgradimo ličnu sposobnost da vladamo stresom, koliko god je to moguće, umesto da stres vlada i upravlja nama.

Neopravdano je da se dete koje je odrastalo pored majke, koja je konstantno živela pod stresom (Pörner, 21), oseća potpuno prirodno pod „turbo modusom“ stresa, jer ne poznaje drugačije mogućnosti ni perspektive.

Stres se prirodno pojavljuje kao reakcija na neočekivane životne probleme i situacije. Neprirodno je kada uključimo sebe u „turbo modus“ i život pod konstantnim stresom, zbog pogrešne percepcije o ličnom profesionalnom uspehu i privatnim porodičnim očekivanjima, izrabljujemo stresom naše telo mesecima, možda čak i godinama.

Iskustvo majke čije dete je sa grupom dece posetilo, „Vladisavljević“ pčelarstvo, predstavlja dobar praktičan primer rehabilitacije stresa. Dečak koji se pod uticajem stresa zatvarao u sebe i sve manje razgovarao, vratio se kući pun oduševljenja ne prestajući da priča šta je sve lepo doživeo u dvorištu „Vladisavljević“ pčelarstva. Vrhunac doživljaja, za ovog dečaka, bilo je jahanje poni konja. Majka je takođe bila srećna, jer je njen sin progovorio i bio potpuno opušten.

\section{Hronični stres, Burn-out i demencija}

Najnovija istraživanja pokazuju da se Burn-out u svojoj prvoj fazi temelji na stresu. U toj prvoj fazi se telo nalazi u permanentnom stanju duboke uznemirenosti. Posledice se oslikavaju u slabljenju imunog sistema kroz umanjenu otpornosti organizma na viruse, kao i simptomima glavobolje i bolova u leđima. Nuspojave ovog stanja su pogoršanje porodičnih i međuljudskih odnosa, kao i gubitak 
interesovanja za omiljene aktivnosti u slobodno vreme. U drugoj fazi nastaje prilagođavanje na izmenjenu hormonalnu ravnotežu. Čini se kao da je telo bez razloga bilo u alarmantnom stanju stresa, bez saznanja protiv čega se bori ili od koga beži. Faza prilagođavanja u toku dužeg vremenskog perioda otvara put malignim oboljenjima, srčanim oboljenjima i bolestima creva. Hronični osećaj umora takođe može biti posledica druge faze Burn-outa. Treća faza predstavlja konstantno funkcionisanje na minimalnom nivou. To znači da je nastala nova ravnoteža između ličnih resursa i svakodnevnih obaveza, otaljavanjem poslova radi štednje preostale životne energije tela (Kitvood, 187-190).

Iz meni dostupnog iskustva, nazirem koliko nekontrolisani dugogodišnji stres ugrožava imuni sistem i celokupno zdravlje pojedinaca. Demencija čini osobe dezorjentisanima u vremenu ili prostoru, mada se događa da neke osobe budu dezorjentisane i u vremenu i u prostoru. To omogućava osobi ugroženoj demencijom, na primer, da bude uverena da živi svoju mladost od pre šezdeset ili sedamdeset godina. Ove osobe putuju kroz proteklo vreme svog života i ponekad izgovaraju rečenice koje su ostale duboko urezane u njihovom umu. Te rečenice oslikavaju nesavladani stres koji leži u osobama po nekoliko decenija. One predstavljaju lični trajan hronični i klinički stress.

Psihoterapeut Jeknić pojašnjava: „Prema tome, opažanje stvara utiske, a utisci produkuju misli koje prerastaju u razmišljanja. Bez redefinisanja utisaka,oni će doživotno imati ulogu kao u momentu nastanka, iako su odavno pogrešni ili prevaziđeni. A tada postaju ozbiljan izvor napetosti i neravnoteže“ (Jeknić, 28).

Najveći uzročnici trajnog, hroničnog i kliničkog stresa su: osećaj usamljenosti, osećaj nepravde, osećaj besmisla i tuge, kao i osećaj krivice i ne praštanja. Ove osobe su istovremeno patile od sekundarnih oblika demencije. Uzroci su na primer: alkoholizam, trovanje toksinima, nedostatak vitamina, nedostatak soli, problemi razmene materija u organizmu, problemi sa imunim sistemom, tumori, psihičke i neurološke smetnje (Mötzing \& Schwarz, 586-587).

\section{Stres i bolesti zavisnosti}

Kada je pod stresom, čovek može da ima sklonost da satima, možda čak i danima, boravi pred televizorom, kompjuterom, ili sa mobilnim telefonom u ruci, ,bombardujući“ svoj um sadržajima, koji ga vremenom čine zavisnim i još više podložnim stresu. Zavisnost se pojačava korišćenjem legalnih lakih droga: duvana, kafe, alkohola, što stvara podlogu za probanje i konzumaciju jakih droga. A sve ovo može da počne stresom zbog izgubljenog posla, gubitkom voljene oso- 
be, ubeđenja o neuspehu u školi ili na poslu, neostvarenih snova, možda i percepcije o bezizlaznoj situaciji, pogrešnim odlukama.

Radeći kao sveštenik, iskusio sam nemoć jednog mladića da ovlada svojim stresom. Bio je sklon da sve planove bazira na emocionalnim odlukama, pa mu je osećaj bespomoćnosti i besmisla snažio uverenje da ne može da iskorači iz vira „svoje realnosti“ u svet realnih perspektiva. Bez volje za bilo kakvim aktivnostima, umnim ili fizičkim, brzo je postao zavistan ne samo od alkohola i duvana, već i od sintetičkih droga. Bile su mu potrebne nove perspektive, novo društvo, novi posao, iskreni prijatelji i „njegov čovek od poverenja“", koga bi mogao da pozove telefonom, ko bi mogao da ga posavetuje, ohrabri, usmeri i pomogne. Bile su mu potrebne godine dobrih odluka, život u dobrom okruženju koje mu pruža podršku u ostvarenju nekog njegovog životnog cilja.

\section{Ravnoteža emocionalnih i racionalnih misli}

Doktor Nidli predlaže: „Kada donosite odluku, razmišljajte analitički i bićete u stanju da se oslobodite procesa robovanja svojim emocionalnim razmišljanjima, koja vas drže u okovima nepoželjnog životnog stila“ (Nidli, 137). Često se događa da strast pali vatru naše inicijative. Kada odluke donosimo na osnovu osećanja, pratiće ih kratkovide akcije i impulsivnost. Rešenje je naći pravu ravnotežu između emocionalnih i racionalnih misli, istovremeno gledajući kakav će uticaj naše odluke imati na našu budućnost i budućnost svih drugih oko nas.

Ravnoteža između emocionalnih i racionalnih misli nam pomaže da popustimo i otpustimo. Onaj ko pusti omogućava stabilnu slobodu i sebi i drugima a kao posledicu doživljava opuštenost. Kontinuiranim puštanjem otvara se prostor za jačanje poverenja, što omogućava da naša opuštenost raste. Važno je pronaći šta je to što je u vlastitom životu stvarno važno (Pörner, 34-37). Kada sagledamo sadržaj našeg ličnog ,stres ruksaka“, koji možda već dugo nosimo na svojim leđima i skupimo hrabrosti da otpustimo nevažno i manje važno, omogućićemo prostor sebi za nešto novo i vredno u životu.

\section{Nove perspektive}

Nove perspektive su ono čime se treba baviti i čemu treba težiti. Nove perspektive se množe kada racionalizujemo i pospremamo sadržaj našeg „stres ruksaka“. Psihijatar Grabe kaže: „Nije lako prihvatiti da mi ožiljci vlastitog života pripadaju, ne odbijajući ih više kao strano telo. Ali, ukoliko prihvatanje uspe, 
ono često otvara neočekivane nove mogućnosti koje su nastale iz neponovljivosti mog novonastalog bića" (Grabe, 142).

Vera je pokretačka snaga koju ne bi trebalo izostaviti u procesu savladavanja stresa. U svojoj knjizi „Ribari ljudskih duša“, Šušnjić kao sociolog religije, u jednom poglavlju se bavi religioznim propovedima: „Bog je potreban i zato ga mora biti. Bog će živeti sve dotle dok ljudi budu imali potrebu verovanja. Manipulacija vernicima, u obliku religioznih propovedi, zasniva se na istim načelima, saznanjima i tehnikama, kao i svi drugi oblici manipulacije, i zbog toga ću ovde samo naznačiti ono, što sam sistematski razvio govoreći o pojedinim elementima manipulacije“, ilustrujući tematiku Ničeovom konstatacijom „Sad u meni pleše bog“ (Šušnjić, 195-196). U teološkom, psihološkom, apiterapeutskom i zdravstvenom smislu, u cilju prevazilaženja stresa i posledica stresa, smatram konstataciju „sad u meni pleše bog“" veoma korisnom i neuporedivo boljom od konstatacije „sad u meni pleše stres“. Moje lično iskustvo je da religiozne propovedi imaju opuštajuće delovanje utemeljeno u sili vere koja uspešno razgrađuje stres. Zato ne smatram religiozne propovedi manipulacijom već jednim sredstvom opuštanja, koje podstiče ravnotežu između emocionalnih i racionalnih razmišljanja.

Sa velikom odgovornošću i pažnjom, apiterapija pristupa svakom korisniku. Kako fizičke, tako i emocionalne teškoće, bivaju uzete u obzir i prihvaćene u proces lečenja. Apiterapija koristi moć prirode i radi zajedno sa drugim granama alternativne medicine (Eder, 37).

\section{Stres i ishrana bogata masnoćama ili industrijskim šećerom}

Možda se događa da obrokom obilnim masnoćama ili šećerom uzrokujemo rat između štitne žlezde $i$ insulina, jednog od najvažnijih hormona u našem organizmu. U borbu se odmah uključuje kortizol, još jedan iz grupe najvažnijih hormona, da bi očuvao ravnotežu šećera u krvi, pa tako slabi naš imuni sistem i uzrokuje mnogobrojne zdravstvene probleme (Panagos, 26-27). Zato, ne treba da nas čudi da se osećamo loše, umorno i napeto, jer smo lošom ishranom prouzrokovali hormonalnu neravnotežu u vlastitom organizmu i tako pokrenuli lavinu zdravstvenih problema, kojima prethodi hormonalna neravnoteža i pojava stresa.

Za razliku od industrijskih šećera koji se dugo vare u želucu i ostavljaju oštećenja za sobom, med nam daje dobre šećere za naše organe za varenje i celokupni organizam. Šećeri iz meda,grožđani i voćni šećeri, ostavljaju sluzokožu želuca u neoštećenom stanju. Grožđani šećer biva odmah prosleđen iz želuca pomoću hormona insulina direktno u mišiće i mozak, kao sveža energija. Voć- 
ni šećeri se polako i postepeno oslobađaju i odlaze u krvotok. Veći deo ovih šećera će tek kasnije u jetri biti upotrebljeni. Na ovaj način, putovanje voćnog šećera kroz organizam teče bez problema i bez prisustva insulina, što je veoma dobro. Voćni šećeri stvaraju takođe zaštitnu sluznu opnu želuca, što je takođe dobro (Schröder, 25).

\section{Postizanje hormonalne ravnoteže}

Za postizanje hormonalne ravnoteže, ekspert za ishranu, Panagos predlaže plan ishrane koji omogućava: bolji san, redukciju stresa, bolje varenje, više životne energije, uravnoteženu telesnu težinu, kao i osećaj sreće (Panagos, 11).

Aneta Šreder u svojoj knjizi predstavlja desetak jela sa medom kao osveženje ishrani. Savetima o ishrani i preparatima za ličnu higijenu i negu tela, takođe daje dobra rešenja u izbegavanju upotrebe toksina u domaćinstvu (Schröder, 51-99). Toksini su razbojnici koji se predstavljaju kao da su hormoni i ulaze na velika vrata u naš organizam. Organizam se obraduje hormonu, a posle ne može da se oslobodi razbojnika koji mu uništava imuni sistem i pravi podlogu za maligne bolesti.

\section{Aktivan boravak u prirodi}

Donesimo odluku da bar jedan deo slobodnog vremena ne provodimo kod kuće. Potrebno je da se potrudimo da izađemo na sunce. Živimo u geografskom području koje obiluje brojem sunčanih dana u toku godine, ali tu prednost ne koristimo dovoljno, jer većinu vremena provodimo u zatvorenom prostoru. Nedovoljan boravak na otvorenom prostoru uzima svoj danak na mozgu usled nedostatka D vitamina i odgovoran je za ometanje mentalnih sposobnosti i pokretanje depresije (Nidli, 281-282).

Umesto udisanja čestica izduvnih gasova u velikim gradovima, što uzrokuje sve veći broj osoba umrlih od infarkta i moždanog udara (Nidli, 285), dobro je makar vikendom disati čist i svež vazduh u obližnjem rezervatu prirode, ili upijati zrake sunca na svežem vazduhu praktikujući aktivni odmor u seoskom turizmu, ili uživati kod pčelara udišući pčelinje aerosole u apikomori.

\section{Lekovito dejstvo pčelinjih proizvoda i preparata}

Opuštajuće lekovito dejstvo pčelinjih aerosola iz košnice su Valerij Sinelnikov i Mikola Jarovij, primenili na opuštanje stresa i nesanice. Korisnik terapije, 
u prostoru izolovanom od prisustva pčela, prespavao je celu noć bez prekidanja, uz opuštajuću zuku pčela inhalirajući lekovite sastojke pčelinjih košnica (Münstedt \& Hoffmann, 249).

Sa posebno snažnim dejstvom, u vazduhu iz pčelinje košnice, ističu se eterična ulja i sitne čestice propolisa. Udisanjem ovog vazduha disajni putevi bivaju dezinfikovani i osnaženi antibiotskim dejsvom propolisa (Thuile, 138).

Redovnim uzimanjem pčelinjih proizvoda, prema savetima apiterapeuta, možemo da postignemo bolji rad krvotoka i jačanje imunog sistema (Krämer, 117), kao i izlučivanje toksina iz organizma (Stangaciu, 125).

Pčelar se uči strpljenju od pčela. One same su u stanju, ako je potrebno, da se strpe i po tri meseca da ne izlaze iz košnice i ne vrše nuždu (Terzin, 236). Pčelar, kada je opušten i strpljiv i ima lagane pokrete, u ravnoteži je sa pčelama, prirodom i samim sobom. Biti pčelar, ili biti u društvu sa pčelarom i pčelama, znači posedovati prirodne tehnike opuštanja od stresa.

\section{Pčelinji proizvodi i preparati}

Savetovanjem sa apiterapeutom uzimati:

- med u dnevnoj dozi od 5 do $30 \mathrm{~g}$

- propolis 3 puta dnevno između obroka, uzeti 3-10 kapi propolisa (Stangaciu, 129)

- inhalacija pčelinjim vazduhom u apikomori, najmanje 30 minuta dnevno

- matičnu mleč uzimati 3 puta dnevno pre obroka u maksimalnoj dnevnoj dozi od 1-3g

- polen, svež ili zamrznut, uzimati takođe 3 puta dnevno, ali posle obroka u ukupnoj dnevnoj dozi od $30 \mathrm{~g}$

- perga (pčelinji hleb) uzimati $10-20 \mathrm{~g}$ dnevno

- vosak poklopaca meda, 5-20g žvakati, a zatim progutati (Stangaciu, 129)

- pčelinji otrov kao krema nanosi se na odgovarajuće akupunkturne tačke ili bolna mesta

- apipunktura, nakon urađenog alergotesta, može se vršiti mikro pčelinjim ubodima kroz plastičnu foliju na odgovarajuća akupunkturna mesta, dva do tri puta sedmično (Stangaciu, 144). Terapija počinje sa dva pčelinja uboda po terapiji, a zatim se prelazi na po tri pčelinja uboda (Krämer, 117). 


\section{Preparati:}

\section{Preparat koji umanjuje stres kod odraslih i dece}

Sastojci:1 kašika pčelinjeg meda, 1 kašika pčelinjeg polena (pola kašike polena za decu), 1 kašika jabukovog sirćeta. Priprema i primena: sve sastojke promešati u čaši mlake vode i popiti; preparat se može koristiti tri do četiri sedmice bez pauze (Oppermann, 49).

Preparat koji umanjuje stres, nervozu, kašalj i bolove grla pri gutanju

Sastojci: 250 g lipovog meda, 50 g jabukovog sirćeta. Priprema: sve sastojke promešati u braon staklenoj flaši. Rok trajanja: 3 godine na hladnom i tamnom mestu. Primena: preparat, za blago opuštanje, u količini od 50 g pomešati sa pola litre lipovog čaja i piti ujutro i uveče (Nedoma, 103).

Preparat za jačanje imunog sistem, regeneraciju organizma, deluje antioksidativno i štiti ćelije organizma

Sastojci: 300 g meda, 100 g jabukovog sirćeta, 3 kašike pčelinjeg polena, 1 kašika perge, 1 kašika Tinkture propolisa u jabukovom sirćetu, 1 kašika pčelinjeg mleča. Priprema: sve sastojke promešati u braon staklenoj flaši. 3 dana ostaviti da odstoji i povremeno promućkati. Filtrirati i flaširati u braon staklenu ambalažu. Rok trajanja: godinu dana na hladnom i tamnom mestu. Primena: Tri kašike preparata razmutiti u čaši vode, ili čaja i popiti. Za akutne zdravstvene probleme uzeti 50g preparata i razmutiti u 1 litri vode ili lekovitog čaja i popiti u toku dana. Za akutni kašalj uzeti jednu kašičicu oralno. Pre upotrebe dobro promućkati (Nedoma, 118).

Preparat koji ublažava stres, nervozu, kašalj i bolove grla pri gutanju

Sastojci: 3 dela livadskog meda, 1 deo jabukovog sirćeta, 1 deo svežih cvetova lavande. Priprema: jabukovo sirće i sveže cvetove lavande kuhinjskim mikserom promešati u braon staklenoj flaši. Ostaviti da prenoći pa dodati med. Ostaviti da odstoji sedmicu dana, a zatim filtrirati. Rok trajanja: godinu dana na hladnom i tamnom mestu. Primena: Preparat zahvaljujući lavandi, ima umirujuće i opuštajuće dejstvo. Deluje opuštajuće na stres i ublažava depresiju (Nedoma, 127).

\section{Preparati za ličnu higijenu i negu tela na bazi meda}

\section{Šampon sa medom i ruzmarinom}

$240 \mathrm{ml}$ čaja svežeg ruzmarina, $5 \mathrm{~g}$ ksantan, $4 \mathrm{~g}$ D-pantenol, $40 \mathrm{~g}$ tečnog lipovog meda, $180 \mathrm{~g}$ Tensid. Dodaci: $2 \mathrm{~g}$ svileni protein, $2 \mathrm{~g}$ ekstrakt breze, $1 \mathrm{~g}$ organskog sumpora, $1 \mathrm{~g}$ alfa-bisabolol, $1 \mathrm{~g}$ vitamin A-palmitat, 20 kapi ulja ruzma- 
rina. Priprema: čaj svežeg ruzmarina i ksantan dobro izmešati mikserom. D-pantenol, med, dodatke i ulje ruzmarina takođe promešati mikserom. Tensid pažljivo promešati mikserom (Schröder, 51).

\section{Šampon sa medom i kamilicom}

$240 \mathrm{ml}$ čaja kamilice, $5 \mathrm{~g}$ ksantan, $4 \mathrm{~g}$ D-pantenol, $40 \mathrm{~g}$ tečnog lipovog meda, $180 \mathrm{~g}$ Tensid. Dodaci: $2 \mathrm{~g}$ ekstrakt kamilice, $2 \mathrm{~g}$ svileni protein, $1 \mathrm{~g}$ alfa-bisabolol, $1 \mathrm{~g}$ vitamin E - acetat, $1 \mathrm{~g}$ vitamin A - palmitat, 20 kapi ulja kamilice. Priprema: čaj sveže kamilice i ksantan dobro izmešati mikserom, D-pantenol, med, dodatke $\mathrm{i}$ aromatično ulje takođe promešati mikserom.

Tensid pažljivo promešati mikserom (Schröder, 51).

\section{Gel za tuširanje sa medom i lavandom}

$240 \mathrm{ml}$ čaja od lavande, $0,5 \mathrm{~g}$ limunske kiseline, $15 \mathrm{~g}$ glicerina, $5 \mathrm{~g}$ hantan, $15 \mathrm{~g}$ bademovog ulja, $5 \mathrm{~g}$ lisolecitina, $4 \mathrm{~g}$ D-Pantenola, $40 \mathrm{~g}$ tečnog meda, $1 \mathrm{~g}$ rokonsala BSB-N, $180 \mathrm{~g}$ tensida za negu lica, $1 \mathrm{~g}$ vitamin E - acetat, 20 kapi etarskog ulja lavande. Priprema: čaj lavande, limunsku kiselinu i glicerin izmešati u posudi. Hantan mikserom temeljno izmešati. Ulje badema i lisolecitin dobro promešati mikserom u gel za tuširanje. D-panthenol, tečni med ulje lavande umešati mikserom. Rokonsal BSB-N dobro obraditi. Face-tensid pažljivo mikserom promešati (Schröder, 54).

\section{Kremast sapun sa medom}

$250 \mathrm{~g}$ kokosovog ulja, $100 \mathrm{~g}$ babasu ulja, $30 \mathrm{~g}$ pčelinjeg voska, $250 \mathrm{~g}$ suncokretovog ulja, $200 \mathrm{~g}$ ulja uljane repice, $40 \mathrm{~g}$ ricinusovog ulja, $130 \mathrm{~g} \mathrm{NaOH}-$ pelets, $200 \mathrm{ml}$ destilovane vode, $50 \mathrm{~g}$ šea puter, $40-50 \mathrm{~g}$ lavandinog ulja, $100 \mathrm{~g}$ meda, $100 \mathrm{ml}$ tečnog kajmaka (milerama). Priprema: iz $\mathrm{NaOH}$ - pelets i destilovane vode napraviti sodinu vodu i ostaviti da se ohladi. Kokosovo ulje, babasu ulje i pčelinji vosak zajedno otopiti. Suncokretovo ulje, ulje uljane repice i risinusovo ulje dodati i sve dobro promešati. Sodinu vodu pridodati masnoćama. Sve zajedno najmanje sat vremena, pri temperaturi od $80-90^{\circ} \mathrm{C}$ držati da osapuni. Šea puter i lavandino ulje dobro promešati. Med i mileram sjediniti i pridodati sapunu. Sapun ostaviti malo da se ohladi i formirati kuglice sapuna (Schröder, 58).

\section{Zdrav jelovnik na bazi meda}

Šećeri iz meda, grožđani i voćni šećeri, ostavljaju sluzokožu želuca u neoštećenom stanju. Grožđani šećer biva odmah prosleđen iz želuca pomoću hormona insulina direktno u mišiće i mozak, kao sveža energija (Schröder, 25). 
Svoje opuštajuće dejstvo, med uspešno ostvaruje i preko zdravih jela bogatih biljnim masnoćama, kao i sastojcima meda. Predstavićemo vam dva jela sa medom.

\section{Plavi patlidžan sa medom}

Sastojci (za 4 porcije): $500 \mathrm{~g}$ plavog patlidžana, $100 \mathrm{ml}$ maslinovog ulja, 4 čena belog luka, 1 vezica peršuna, 1 vezica majčine dušice, $100 \mathrm{ml}$ vode, 2 kašike balzamiko sirćeta, $20 \mathrm{~g}$ meda, so i beli biber iz mlina. Priprema: iseći plavi patlidžan na kockice veličine $2 \mathrm{~cm}$, staviti u posudu i dobro osoliti. Ostaviti $15 \mathrm{minu}-$ ta da odstoji. Staviti u sito, isprati hladnom vodom i osušiti kuhinjskim papirom. Po porcijama (4 porcije) zapeći u maslinovom ulju i staviti na kuhinjski papir da se ocedi. Crni i beli luk sitno iseckati i ugrejati u maslinovom ulju, ali ne pržiti. Med, vodu i balzamiko sirće umešati. Fino iseckan peršunov list dodati u kockice plavog patlidžana, a zatim začiniti solju i biberom i ostaviti kratko vreme da se kuva. Najukusnije je toplo sa taze hlebom (Schröder, 82).

\section{Taljatele sa bosiljkom i medom}

Sastojci (za 4 porcije): testenina/taljatele, $200 \mathrm{~g}$ svežeg bosiljka, 1 čen belog luka, pinola semenke ili indijski orah, 3 kašike sveže naribanog parmezana, $100 \mathrm{ml}$ maslinovog ulja, 2 kašike meda, 2 kašike sveže ceđenog limunovog soka, 1 čaša milerama (pavlake), $250 \mathrm{ml}$ tople vode začinjene vegetom, 50 g crnih maslina bez koštice, so i biber iz mlina, sitno seckane ljute čili papričice. Priprema: bosiljak umešati mikserom zajedno sa belim lukom, pinola semenkama ili indijskim orasima, naribanim parmezanom, sokom limuna, maslinovim uljem i medom. U izmešan bosiljak sa dodacima, pridodati pavlaku i vodu začinjenu vegetom. Kuvati u posudi 15-20 minuta, dok se sos ne zgusne. Začiniti solju i biberom. Masline grubo iseckati. U međuvremenu skuvati testeninu, pomešati sa sosom od bosiljka i meda i servirati na tanjire. Iseckane masline, iseckane čili papričice i naribani parmezan, posuti od gore (Schröder, 92).

\section{STRAHOVI U USLOVIMA SAVREMENE PANDEMIJE}

Strah u uslovima savremene pandemije značajno podiže cene namirnica i određenih obaveznih artikala zaštite, kao na primer: zaštitnih maski, rukavica i sredstava za dezinfekciju. Strah takođe doprinosi da se ovi artikli prodaju u mnogo većim količinama.

Posledice savremene pandemije su vidljive u svim delovima privrede. Radnici u proizvodnji, trgovini i uslugama većim delom rade skraćeno radno vre- 
me. Ima i onih koji su ostali bez posla. Pandemija je sa sobom donela i novi način nege starih osoba. Umesto nege u staračkim domovima, očigledna je sve veća potražnje usluge nege starih i bolesnih kod kuće, pa starački domovi beleže sve veći broj slobodnih kreveta. Kuhinje , restorani i hoteli su već duže vreme preusmereni na skraćeno radno vreme. Novija pojava je da i kuhinje u staračkim domovima prelaze na skraćeno radno vreme. Postoji mogućnost da i osoblje zaduženo za medicinsku negu stanovnika u staračkim domovima uskoro pređe na skraćeno radno vreme. Država za sada sve to dotira sredstvima do pune plate radnika.

Smanjen broj stanovnika u staračkim domovima utiče na smanjenje potrebe za radnom snagom, pa je strah od gubitka posla kod radnika neminovna posledica. Oni koji pokušavaju da se „bolje prodaju“ na tržištu rada, uvereni su da će im tamo negde biti bolje. Drugi čekaju da dobiju otkaz jer se oslanjaju na zakonsko pravo dobijanja osamdeset procenata plate u toku dve godine, ukoliko to pravilo ostane na snazi. Dve godine prođu brzo a retko ko želi radnika koji dve godine ništa nije radio, niti bilo šta učio.

U uslovima savremene pandemije, svaki vakcinisani pojedinac dobija, internacionalni pasoš vakcinacije, izdat od strane Svetske zdravstvene organizacije, koji je skoro identičan pasošu vakcinacije za kućne ljubimce, koji pojedincu omogućava slobodno putovanje po celom svetu, a smatra se pasošem nad svim pasošima. Kada sam iz Švajcarske doputovao u Srbiju, na granični prelaz na Aerodrom Nikola Tesla, shvatih u da službenica nije obavezna da prihvati moj pasoš vakcinacije, jer ne postoji uzajamni međudržavni sporazum između Švajcarske i Srbije o tome. Shvatih i da je za ,zapadni svet“" problem da prihvari odluku države Srbije da bez favorizovanja ,zapadnih“ ili ,,istočnih“ proizvođača vakcine, omugući svojim građanima slobodu izbora kojom vakcinom žele da se vakcinišu. Shvatih i da ja, koji sam vakcinisan „modernom“, jer je tako struka u Švajcarskoj odlučila, mogu slobodno da putujem samo ,zapadnim svetom“. Da bih slobodno putovao ,,istočnim svetom“ trebao bih da se vakcinišem u Srbiji, ali vakcinom nekog, ,istočnog“ proizvođača. Tek vakcinacijom jednom ,zapadnom“ i jednom ,istočnom“ vakcinom bih, po svemu sudeći, ostvario mogućnost putovanja po celom svetu. Potpuno je izvesno da savremena pandemija podseća na vreme ,hladnog rata“.

Nezvanična saznaja ukazuju na donošenje nove regulative, po kojoj će vakcinisani pojedinci moći uskoro bez maske da rade na radnim mestima, kao i da se bez maske svuda slobodno kreću. Favorizovanje vakcinisanih bi sve ostale stavilo u ulogu građana drugog reda. 


\section{Strahovi su čvorište problema}

Sigmund Frojd, baveći se psihoanalizom, naglašava da je strah čvorište problema. On polazi od analize okolnosti pod kojima se strah pojavljuje i zaključuje da postoji realan strah, kao na primer strah od zmije, kada se ona iznenada pojavi pred nama. Reakcija na realan strah može biti „bežanje“ ili „afekt“. Afekt se prema Frojdu ispoljava motoričnim reakcijama na tačno određene događaje i situacije. Ukoliko se određena doživljena situacija ponovi, ponoviće se i određena reakcija na tu situaciju. Bez obzira u kakvim okolnostima i zbog kakvih objekata nastupa opasnost i strah, refleksna reakcija bežanja je unutrašnje ispoljavanje samozaštite (Freud, 375-378).

Frojdov realan strah je prihvaćen u psihologiji, a definisan je kao stres. Reakcije na realan strah tj. stres, „bežanje“ i ,,afekt", pojavljuju se u novijoj psihološkoj literaturi kao „bežanje“ i „borba“ (Pörner, 17-22).

Kada je u pitanju realan strah, Frojd navodi da je normalna reakcija svakog zdravog čoveka da se on uplaši. To je upravo taj realan strah, odnosno stres.

Frojd navodi da postoje i strahovi koji nisu realni, međutim on nikada ne koristi pojam nerealan strah, ali je očigledno da o tome govori.

On takvo stanje naziva strahovima koji izlaze izvan okvira realnog straha tj. stresa. Ukoliko se žena uplaši, ilustruje on, od miša koji se pojavi u prostoriji dok kraj sebe ima snažnog muškarca, to nije realan strah. Frojd ne upotrebljava termin nerealni strah, mada on realno postoji, već se bavi analizom i grupisanjem različitih nerealnih strahova (Freud, 379-385).

Razmišljao sam zašto postoji taj problematičan pristup od strane jedne žene, koja je u prisustvu snažnog muškarca, odnosno zašto se javlja strah od miša koji ne može da joj naudi. Moguće je da je muškarac koji se nalazi u istoj prostoriji u kojoj se nalazi i žena, kao rezultat njenih ispravnih a možda i pogrečnih procena, zaključila da nije osoba na koju se ona može osloniti, ili uz koga se može osećati sigurno. Dakle, razlog zbog kog se pojavljuje takav strah kod žene leži ili u stvarnoj nesposobnosti muškarca da je zaštiti ili u pogrešnim zaključcima njenih razmišljanja.

Frojd spominje strah kao jedan veoma prihvatljiv novčić za koji se mogu protrgovati i razmeniti razna afektna uznemiravajuća stanja pojedinaca, pod uslovom da pretpostavljeni sadržaj bude vezan za neku opasnost (Freud, 385). Upravo taj strah koji ulazi u trgovinu, na neverovatan način naš život čini „začinjenim“.

Ne mali broj osoba se svakodnevno bar jednom uplaši, ispoljavajući to jednim naglim trzajem tela ili ruku. Razlog se krije u iznenađenju nečijom pojavom u njenoj neposrednoj blizini, kao i iznenadni zvuk ili stavljanje ruke na rame te 
osobe. Sigmund Frojd uzrok ovakve reakcije vidi u konstantnom pesimističnom iščekivanju da će se nešto loše dogodi. Simptome ovakvog straha ima gotovo polovina čovečanstva (Freud, 379-380).

\section{Strah dodeljuje uloge u drami}

Frojd smatra da strah uzrokuje stanje afekta i kod nervoznih i kod strašljivih (Freud, 375). Govoreći o nervozi, Frojd primećuje reakcije nervoznih na međuljudske odnose i spoljne uticaje ispoljene njihovom razdražljivošću. Dakle, Frojd svoje izlaganje o neurozi otpočinje opisivanjem onoga koji ima nervozu. Po njemu, u simptomima nervoze važnu ulogu ima udeo vlastitog ,JA“. Veza vlastitog JA sa nervozom je najupečatljivija u toku jednog afekta i podrazumeva traumatsku nervozu. Forme neuroze dolaze do izražaja uvek iznova u ponovljenim okolnostima i trenucima od posebne važnosti za izgradnju simptoma. Reakcije vlastitog JA oslikavaju tačno osmišljene uloge koje se dodeljuju uvek iznova učesnicima drame: heroj, čovek od poverenja, čovek za intrige itd. (Freud, 361-364). Po svemu sudeći, vlastito JA odlučuje kojoj će osobi dodeliti koju ulogu. Na osnovu ličnih iskustava, smatram da se strah iz raznoraznih razloga veoma često nalazi u osnovi nervoze.

\section{Čovekova potreba da prevaziđe svoju usamljenost i strah}

Švajcarska književnica Melinda Nađ Abonji, rođena u Bečeju u Srbiji, koja je kao petogodišnja devojčica otpočela život u Švajcarskoj, u svom romanu „Golubovi se podižu“, veoma jasnim i uverljivim jezikom je ispričala svoju autobiografski obojenu priču emigracije i mladalačkog sazrevanja. Roman je nagrađen 2010. godine Nemačkom nagradom za književnost, a zatim i Švajcarskom nagradom. Do sada je napisala tri poznata romana. Na internet stranici državne televizije stoji i podatak da živi u Cirihu sa sinom (https://ansichten.srf.ch/autoren/melinda-nadj-abonji, pristup 12.5.2021).

Naslovom „Golubovi se podižu“ ili doslovno prevedeno „Golubovi lete na“, Abonji predstavlja sebe u grupi miroljubivih osoba, biofilnih osoba u kontekstu ovog rada, koje kao golubovi lete na neprilike iz kojih se vremenom podižu.

U središnjem delu svog romana Abonji opisuje izlazak sa sestrom u grad (Cirih), jer su pozvane od strane bivših Jugoslovena u jedan klub. Kao sporedna tema razgovora provlači se rat u Bosni i kopanje podzemnog tunela ispod aerodromske piste u Sarajevu. Sledi ispretumbana naracija jave i halucinacija, opisa- 
ne vrhunski izražajnim stilom jezika. Iznenadnim buđenjem, pitala je sestru gde se nalaze i šta tu rade. Sestra joj govori: „Rum i trava se ne podnose, krvava početnice“! Tu se one prisećaju i reči bake iz Bečeja, da svaka osoba ima bar dva, tri lica. Ona pita sestru i zašto su opkoljeni policijom, na šta sestra odgovara da nema policije. Pošto nema noge (halucinira), već joj srce lupa tu gde su joj noge bile, nose je dole u podrumski klub. Kada se probudila, sve joj je bilo lepo, i boje koje cure po zidovima, i srča stakla oko mesta na kojem je ležala. Prisećala se razmene intimnosti sa mladićem sa kojim je plesala a koji joj se baš i nije sviđao. Prisećala se i da se svom snagom opirala da je mladić ne baci u neku rupu. Kada su u svanuće ostale same na železničkoj stanici, autor kaže: „Ja sam nas (sebe i sestru) videla velike; Ja, jedna uzbuđena lepršava golubica, ljudskim koracima zatečena" (Nadj Abonji, 140-145). Ovo je jedno od ispričanih iskustava ličnih ožiljaka, prouzrokovano neočekivanim ljudskim koracima. Mnogo je više onih neispričanih, jer svaka osoba nosi svoje ožiljke i uglavnom ne govori o tome.

Čovekova najveća potreba je da prevaziđe svoju odvojenost, svoju usamljenosti. Strah od potpune izolacije čovek može da prevaziđe radikalnim povlačenjem iz spoljašnjeg sveta, tako da osećaj odvojenosti iščezne. Istovremeno što se više odvaja od sveta prirode, njegova potreba za izbegavanjem odvojenosti je sve veća. Za postizanje ovog cilja praktikuju se određene vrste orgijastičkih stanja, koja mogu biti u formi transa uz pomoć uzimanja droga na primer. Rituali primitivnih plemena koja su praktikovala orgijastičke intimne odnose, kao stvar zajedničke prakse plemena, ne izazivaju osećaj krivice kod pojedinca. U neorgijastičkoj strukturi, pojedinac koji samostalno bira uživanje alkohola ili droge, pati od osećaja krivice ukoliko se njegov izbor smatra društveno neprihvatljivim od strane grupe. Primera radi alkoholizam, uzimanje droge i upražnjavanje intimnih odnosa u cilju izbegavanja teskobe odvojenosti, rezultat je sve snažnijeg osećaja odvojenosti, jer na primer ,intimni čin bez ljubavi nikada ne premošćuje provaliju između dva ljudska bića, sem na trenutak“. Strah od izolacije pojedinac rešava sjedinjavanjem i prilagođavanjem grupi, njenim postupcima, običajima i verovanjima (From, 17-19). Dakle, život u velikim gradovima nudi realnu odvojenost od prirode i strahovitu potrebu grupisanja u cilju preživljavanja strahova koje ovakav stil života nameće.

\section{Dva profila ljudske ličnosti - biofilni i nekrofilni}

Erih From u svojoj krizi o ljudskoj duši, objašnjava da postoje dva profila ljudske ličnosti - biofilni i nekrofilni. Biofilne ličnosti su pozitivne i okrenute 
životu. Ovakve osobe vole prirodu, životinje i ljude. Nekrofilne ličnosti su negativne i usmerene su ka svemu mrtvom i rušilačkom. Sklone su korišćenju uma u svrhu nanošenja gubitaka ljudima, životinjama i prirodi. From je svoju postavku izveo iz one koju je Frojd postavio sa erosom - nagonom na život, i tanatosom nagonom na smrt. Eros, smatra From, gubi svoju funkciju nagona na život u slučaju agresivnih perverznih radnji, i može se smatrati aktom nasilja. U tom slučaju ne možemo smatrati da je eros, uvek nagon ka dobru i životu, već tu mogu postojati momenti gde zbog prisustva agresije i straha, čovek u intimnom činu postaje nasilan, pa nagon na život postaje nagon na smrt. From dodaje da Frojdov nagon na smrt pripada psihopatologiji (Fromm, 54-56). Sve to govori da čovek može da se prepusti i bude životinja svojih navika, kako smatra psiholog Gabi Perner, koja na određeni način oslikava ono što je veoma problematično, odnosno da se čovek prepusti stihiji tokova grupe i da tako svede svoj život na osnovne životne funkcije koje upražnjava jedna životinja (Pörner, 65).

\section{Uloga grupe}

\section{Strah od Boga formira grupu}

Kada govorimo o grupi, najveću pažnju na mene je ostavila grupa koja se pominje na početku Svetog pisma u 3. i 4. poglavlju Prve knjige Mojsijeve. Radi se o Adamu koji se sakrio i kada ga Bog poziva, on kaže: ,uplaših se pa se sakrih“. Dakle, strah je tu bio prisutan. Diktrih Bonhofer, Luteranski pastor, je rekao da svako od nas ima strah od istine i taj strah je u osnovi naš strah od Boga (Amelung \& Strohm, 456). Kada bismo malo dublje posmatrali tu prvu grupu koja se pojavila na Zemlji, primetili bismo da se u njoj nalazi prvo stvoritelj Elohim - Bog, a istovremeno se tu nalazi i sotona, zatim Adam i Eva, kao i njihovi sinovi Kain i Avelj. Sotona je već tu otvoreno pokazao želju da gospodari celom grupom. Posejao je sumnju i strah u ispravnost Božjih reči kod Eve, i predstavio sebe osobom dostojnom poverenja koja može da pomogne grupi.

\section{Trgovina strahom}

Erih From navodi Hitlera, Staljina i inkviziciju kao najupečatljivije primere nekrofilije koje je čovečanstvo doživelo. On takođe navodi da je Ajhman, jedan od prvih saradnika Adolfa Hitlera, bio veoma precizan, perfekcionista u preciznom vođenju knjiga. Sve je bilo potpuno do detalja isplanirano po pitanju lju- 
di koji su bili transportovani u logore. Jedino što se on o ljudima nije puno brinuo, pa je jevreje transportovao kao ugalj, što je ključna karakteristika jednog nekrofila. On nema osećanja prema ljudima, prirodi, životinjama i gotovo da za njega sve počiva na interesu i trgovini (Fromm, 43-45). Zbog toga, po Frojdu, takva osoba je sklona da taj pristupačan novčić upotrebi za trgovinu strahom (Freud, 385), da bi nametnuo strah u grupi, ili da bi ga fokusirao na nekoga koga smatra problematičnim, ili na nekog ko mu na određeni način ne odgova i smeta.

Sa druge strane, važno je pomenuti da su biofilne osobe one koje vole ljude i vole da pomognu, naročito u uslovima savremene pandemije. Jedan prosečan nekrofil je sklon da se bavi pravilima i on ne brine o ljudima već samo vodi računa o tome da se pravila dosledno ispoštuju. Veoma je hladan prema ljudima i nije mu važno da li će ljudi ostati živi, ili će neko morati da umre. Samo mu je važno da sve bude urađeno onako kako pravila i zakoni pandemije nalažu, jer su to sada zakoni koji su iznad svih drugih zakona. Ukoliko neko ne poštuje ta pravila tako striktno i stoprocentno, jedan prosečan nekrofil je spreman da stisne pesnicu i paraverbalnom komunikacijom pokaže svoju agresiju, ili kažiprstom počinje da preti. Sve su to elementi koji se mogu neverbalno pojaviti, a istovremeno i paraverbalno u samoj boji glasa određene osobe (Ruckh, 19-24).

\section{Strahovi unutar grupe}

„Strah je, dakle, opšte prihvaćeni upotrebljiv novčić koji se može razmeniti za sve unutrašnje pokretače afekta“ (Freud, 385). Možda se pitate u kom smislu je to značajno?! Značajno je u tom smislu jer je taj strah vezan za grupu. Ukoliko ne bi bilo straha, ne bismo imali potrebu da se udružujemo, jer mi zbog straha tražimo utočište u grupi. Kada se ljudi okupe u grupi, u početku im ta grupa pomaže da prebrode svoj strah, ali veoma brzo se dogodi da ta grupa vrši uticaj na pojedince u grupi, čime se oni, pojedinci nalaze u nezgodnoj situaciji, pa se moraju odlučiti šta će učiniti - da li će se podrediti grupi, ili će nastaviti da se drže svojih ličnih stavova.

Ukoliko se pojedinac odluči da se drži svojih ličnih stavova, imaće za posledicu da ga njegova grupa sve više i više ignoriše i na kraju izostavi iz grupe. U tom smislu, ta trgovina tim strahom, odnosno novčićem koji se može dobro razmeniti u svakoj situaciji, je vrlo specifična, ali i interesantna stvar, jer grupa uvek ima mogućnost da se u njoj pojave osobe koje imaju potrebu da se istaknu, potrebu za dominaciojom, potrebu za postizanjem svojih izvesnih ciljeva i zato koriste strah kao taj novčić sa kojim može da se trguje sa svim agresijama i strahovima pojedinaca. 
Samo je pitanje trenutka, kada će jedna osoba koja ima želju i potrebu da sebe nametne kao vođu grupe, usmeriti te strahove u određenom smeru sa „novčićem straha“, odnosno kada će usmeriti sve agresije i gnjev grupe na određenu osobu ili određene pojedince unutar grupe.

\section{Agresije unutar grupe}

U slučaju isklizavanja iz ravnoteže emocionalnih i racionalnih misli, o čemu godori doktor Nidli, kao i nemogućnosti praštanja sebi i drugima, o čemu govori psihijatar Grabe, sledi kulminacija agresija od verbalnih ka fizičkim što je jedan jasan put nekrofilnosti, koja ima za cilj da ukloni onoga koji mi stoji kao prepreka posedovanju onoga što mi po mojim „realnim“ očekivanjima pripada. U tu svrhu nekrofilni iz grupe se udružuju, pokrenuti unutrašnjom bujicom nerealnih strahova i percepcije, da spasu grupu, pa su počastvovani svojom neprocenjivom ulogom u spasavanju grupe, pozivajući se na nove zakone i pravila, kao i na vanredna pravila i zakone zbog pandemije, koje treba nadopuniti njihovim planovima izostavljanja problematičnih iz grupe, koji ne dele njihove stavove. Dok se nekrofilni bave pitanjima koga treba izostaviti, biofilni aktivno pomažu svakome kome je pomoć najpotrebnija. Nekrofilni ne pomažu ako nemaju materijalnu korist ili npr. unapređenje statusa makar unutar grupe. Nekrofilni su za promene ali nikada ne polaze od toga da sebe promene, već vrše pritisak na grupu, da je promene i prilagode svojim interesima. Nekrofilni pojedinci grupe prirodno grade grupu unutar grupe koja u grupi nameće svoju dominaciju. Grupa nekrofilnih ima prirodnu potrebu divljenja sobom i svojom ulogom gospodarenja. Gospodari i sluge trebaju jedni druge i žive u korelaciji koju Berđajev lepo opisuje, što je prikazano u prethodnom delu ovog rada (Berđajev, 126). Strašljivi pojedinci bivaju prihvaćeni kao sluge nekrofilnih nižerangiranih gospodara, iz grupe nekrofilnih gospodara, unutar jedne grupe. Legalno i formalno izabrani vođa grupe obično dobija ulogu sluge od strane nekrofilne grupe unutar cele grupe. Kada grupa nekrofilnih gospodara uvidi da novi vođa više radi samostalno nego što sledi njihove instrukcije, tj. ne ponaša se kao njihovo vlasništvo, biva odmah angažovana sva raspoloživa snaga nekrofilnih, na celoj hijerarhijskoj lestvici, na iznalaženju grešaka za optuživanje vođe na svim instancama. Za kratko vreme, nekrofilni gospodari, nekrofilni niže rangirani gospodari, kao i uplašene biofilne sluge, će orkestriranom velikom većinom grupe raditi na izostavljanju novog vođe iz grupe. Dolaskom sledećeg novog vođe grupe počinje novo usaglašavanje stavova i uloga. Nekrofilni gospodari će doživeti bujicu oduševljenja kada uvide da je novoizabrani vo- 
đa grupe nekrofilni tip ličnosti, ali će i on dobiti samo ulogu sluge da bi snagom struke uplašio i prisilio ostatak slobodnih biofila u strukturu, radi uspostavljanja kontrole i dominacije nad celokupnom grupom. Kada se uspostavi apsolutna dominacija nekrofilnih, tj. dominacija ,sile straha i agresije“ nad celom grupom, nastaju sukobi zbog nove podele uloga unutar grupe koja samo verbalno i neverbalno oslikava empatiju, kao i staranje za ljude u grupi. Samo biofili će čuti da paraverbalna komunikacija nije u skladu sa onim što se verbalno i neverbalno dramatizuje. Umesto sile nebeske ljubavi i prave empatije, grupom zavladala sila straha i mehaničke empatije. Svaki biofil koji ne želi da zavisnost od ovakvog uređenja grupe menja za svoju slobodu, vrlo brzo napusti grupu jer u grupi ,nije više lepo“. Oduševljenje nekrofilnih, sobom i svojom ulogom na svim nivoima hijerarhijske lestvice, postaje neopisivo. Radi trajnog oduševljenja grupe, vodeći nekrofilni gospodari grupe redovno iznalaze bar po jednog pojedinca grupe koji „ne odgovara“, koji „nije upotrebljiv“, „kojeg ne možeš koristiti“, koga treba izostaviti iz grupe. Revno se uvek iznova pokreće uhodana mašinerija za optužbe i osude. Uklanjanjem pojedinaca, od čega ni nekrofilni gospodari najvišeg ranga u grupi nisu izuzeti, grupa redovno slavi uspehe i raduje se dokle god grupa još može da postoji. Očigledno je da u ovom „vražjem krugu“ izostavljanja pojedinaca iz grupe, grupa samoubija svoje postojanje. Odvajanje biofilnih od nekrofilnih nije potrebno planski sprovoditi. Svako plansko sprovođenje nekrofili bi rado i sa uživanjem preuzeli na sebe, jer oni to već prirodno ali tajno rade unutar svake grupe, jer to je deo njihove ličnosti. Biofilni i nekrofilni se prirodno odvajaju jer biofilni paraverbalno čuju ko je „sasvim drugi tip“ ličnosti. Dok biofilne povezuju i opuštaju empatija, pozitivne emocije i pomaganje drugim ljudskim bićima, nekrofilne povezuje agresija protiv drugih ljudskih bića. Nekrofilni imaju veoma visoko mišljenje o sebi i „programirani su“ da dele ljude u grupi na „,dobre“ i „loše“, pa su zato u neumornoj potrazi za „lošima“ koji se ne uklapaju u njihovu strukturu gospodarenja. Dakle, na udaru su biofilni jer su kao i Hristos slobodni, „slobodni od sveta“ (Berđajev, 126). Nekrofilni ne mogu svojim umom da shvate jednakost ni humanost ljudskih bića, već poznaju samo „nepisana pravila hijerarhije gospodarenja“.

Služenje i stroga poslušnost gospodarima grupe je motivisana penjanjem na toj hijerarhijskoj lestvici, koje kao dugoročni cilj ima gospodarenje grupom. Biofilni nikada ne veličaju sebe jer sebe smatraju jednakima sa drugima i slobodnima da u svakom trenutku priskoče da pomognu i stave svoje lične intelektualne, fizičke, pa čak i materijalne snage na raspolaganje. Spremnost biofilnog da odmah pomogne svakome kome je pomoć potrebna, nekrofilni vidi kao npr. 
„psa lutalicu“ koji nema svog gospodara, „tumara nekontrolisano naokolo radeći šta namisli“" i ugrožava strukturu hijerarhije. Zbog potrebe za ogromnim brojem gospodara u Nekrofilnoj grupi moguće je primetiti npr. ,gospodara od nege jedne zasađene ruže u vrtu“. Svojom gospodarskom ulogom on sebe vidi za nijansu sposobnijim od npr. ministra za ekologiju u vladi države. Tom ružom, ,gospodar za negu ruže u vrtu“ je dobio svoj smisao postojanja i gospodarenja. Zato je tom ,gospodaru“ ta ruža važnija od njega samog, jer bez nje on nije gospodar i gubi razlog svog postojanja u grupi a možda i uopšte. Taj ,gospodar za negu ruže u vrtu“ je ravnopravan sa nekim ko je od nekrofilnih dobio ulogu npr. „gospodar za posmatranje prolaznika na četrdesetom uglu grada“. Ova dva gospodara su dva ravnopravna ortaka. Svi više rangirani gospodari, sve do ,gospodara nad gospodarima grupe" zavređuju njihovo strahopoštovanje i obožavanje na neki način. Isto takvo strahopoštovanje očekuju od svojih slugu i od svih slobodnih neintegrisanih biofila u strukturu hijerarhije. Kada se ovim najniže rangiranim gospodarima grupe obrati nova nepoznata osoba u grupi, oni je vrednuju kao običnu stvar sve dok ne dobiju informaciju iz nekrofilne hijerarhije grupe, koji je status i ulogu nova osoba dobila. Ta informacija dolazi od ,gospodara nad gospodarima grupe“ i spušta se lestvicu po lestvicu na već postojećoj nekrofilnoj strukturi hijerarhije.

Odgovorno zalaganje ,gospodara za posmatranje prolaznika na četrdesetom uglu grada“" očituje se kroz dokumentovano prijavljivanje npr. svih prolaznika koji su bez maske stajali na autobuskom stajalištu na četrdesetom uglu grada. Svi izgrednici će poštom dobiti da plate kazne za navedeni prekršaj. „Gospodar za posmatranje prolaznika na četrdesetom uglu grada“ neće primetiti ili neće reagovati ukoliko prolaznik usled korone ili neke druge zdravstvene tegobe padne na ulici i neće prilaziti da pomogne, jer je on već zauzet svojom obavezom posmatranja i ne može da zapostavi svoju ugovorenu obavezu i izađe izvan okvira svojih nadležnosti. Slučajem palog prolaznika, po njegovom ubeđenju, treba da se bavi neko drugi ko je za to nadležan.

Nekrofilnom logikom, dom zdravlja koji nije prijavio delatnost primanja hitnih slučajeva, npr. pacijenta koji je pao na ulici u neposrednoj blizini doma zdravlja, nije u mogućnosti da preko reda uradi snimak moguće frakture palog prolaznika. On će morati da sačeka sat - dva vremena do slobodnog termina, jer ga niko ne pušta preko reda, tj. niko se ne odriče svog termina u korist unesrećenog.

Ukoliko nekrofilni pojedinac izgubi ovlašćenje i ulogu grupe, da poseduje nekoga ili nešto, što se za nekrofilne svodi na istu vrednost, on je spreman da iz- 
gubi tj. oduzme sebi život. Razlog se krije u dubokom strahu od života, koji ga ispunjava (Fromm, 43-44). Insceniranjem gubitka života u okolnostima gde je on u ulozi ,žrtve“, čini ga besmrtnom legendom i uzorom novim generacijama nekrofila.

\section{Prva nastala grupa}

Šest osoba se nalazi u ovoj prvoj malenoj grupi na planeti Zemlji, kako to Sveto pismo opisuje. Ono što je interesantno jeste da kada je došlo do postupaka koji su bili posledica nepoverenja u Boga, Bog daje određena obećanja, da će žena dobiti potomstvo i da će tim potomstvom uspeti da se izbori sa zmijom tj. sotonom, iz čega lično smatram da je moguće da su Adam i Eva upali u tu situaciju da poveruju da će možda njihov prvi sin igrati važnu ulogu, pa će im omogućiti da se vrate u Edemski vrt i da se odmah premosti taj jaz koji ih je odvojio od Boga i kvaliteta života u edemskom vrtu. Zato, kada dobijaju prvog sina, Eva kaže „dobih čoveka od Gospoda“ (1. Mojsijeva 4, 1). Dakle, interesantna je činjenica da je prvo dete dobilo ulogu da bude čovek. On je u pravom smislu za njih bio čovek, čovek na kojeg se mogu osloniti, čovek koji će možda i biti na određeni način spasitelj cele grupe. Onda se rađa i drugi sin, i tada Eva gotovo da nema ništa veliko da kaže već samo Avelj - ruah para - ništavilo (1. Mojsijeva 4, 2). Za mene je interesantno da se tu sada nalaze dva mlada bića, od kojih se od jednog očekuje da bude čovek i da ponese teret prevazilaženja nastalog jaza i time omogući da se grupa vrati u Edemski vrt, odnosno povrati ono što je izgubila, dok se od drugog ne očekuje gotovo ništa. On je gotovo para, on je nešto što nema gotovo nikakvu vrednost. Ipak, na kraju se događa da onaj na koga se polagala vrednost, ubija svog brata koji prema očekivanjima većine iz te grupe, nije imao nikakvu vrednost. Ono što još više privlači moju pažnju, jeste da kada se sve to odigralo, na kraju se pojavljuje samo Bog koji pita: „Gde ti je brat Avelj“?! To pitanje ne postavljaju čak ni roditelji. Njihovo ćutanje mi ostavlja utisak da su se oni možda plašili da i oni sami ne završe kao Avelj, ili ponovo nisu bili sigurni šta je ispravno, pa su se možda čak i kolebali da je stvarno bilo potrebno da se problem između dva brata bilo kako reši. To su sada spekulacije koje bi trebale da nam samo predstave prostor u ukviru kojeg se kreće grupa svojim razmišljanjima. $\mathrm{Na}$ ovaj način možemo jasnije razumeti šta je ono što se dešava gotovo u svakoj grupi, koja pokušava da živi zajedno, a koja istovremeno ima problem straha koji ne može da prebrodi. 


\section{Sukobi unutar grupe pojačavaju intenzitet straha}

Taj sukob u grupi, koji se pojavljuje na početku Svetog pisma, gotovo je nešto što se pojavljuje kroz sva vremena ljudske istorije. Velika je prednost biti u jednoj grupi, gde su osobe koje poznaju, vole Boga i proučavaju Sveto pismo. Količina biofilnosti i količina biofila koje poseduje jedna takva grupa, može da napreduje i Hristovom ljubavlju ostvari unutrašnju promenu u celoj grupi, tako da cela grupa može doživeti mir i opuštenost.

Interesantno je da sam doživeo situacije kada je došlo do promene unutar grupe. Tada mi je jedna gospođa, koju sam posetio rekla: „Ovde više nije lepo“. Razlog za to je što više nema empatije, ljubavi, nema saosećanja, nema zalaganja za ljude, sve je svedeno na mehaničko odrađivanje posla, jer oni koji su se nametnuli kao vođe grupe gotovo da taj elemenat ljubavi, saosećanja prema ljudskom biću, prema biljkama, životinjama, prema prirodi gotovo i da nemaju.

Ono što takođe privlači pažnju jeste da čovek koji se udaljava od prirode i koji nema emocije i osećanja, on ima potrebu da u savremenom društvu gradske sredine sebe pridruži u određenu grupu koja će standardizovati njegovo ponašanje, njegove navike, i gde će on jednostavno na hijerarhijskoj lestvici naći odgovarajuće mesto za sebe. Naravno da na toj hijerarhijskoj lestvici postoji problem, jer uvek postoji taj sukob interesa da mnogobrojni žele da se nametnu kao vođe i da svako želi da bude dominantan, jer nekrofili žele da dominiraju i vladaju, (From, 17-19) pa se time nameće problematika da umesto one dobre mogućnosti koja postoji da bi se prevazišao problem onoga što čovek ima kao ruksak na svojim leđima - ,stres ruksak“, pa da može da proanalizira njegov sadržaj i da se oslobodi od nepotrebnog balasta (Pörner, 37).

Postoji problem u tim strahovima, jer čovek nema mogućnosti da se njih oslobodi pomoću grupe. Psihijatar Martin Grabe kaže: „Potrebno je prihvatiti da nam ožiljci našeg vlastitog života pripadaju“ i prihvatanjem mi u stvari priznajemo i praštamo sebi a onda i drugima. „Nije lako prihvatiti da mi ožiljci vlastitog života pripadaju, ne odbijajući ih više kao strano telo. Ali, ukoliko prihvatanje uspe, ono često otvara neočekivane nove mogućnosti koje su nastale iz neponovljivosti mog novonastalog bića“" (Grabe, 142). Okolnosti pod kojima su se određene stvari izdogađale, onako kako nije baš najbolje, onako kako to stres u nama proizvede, ukoliko se te stvari ne prerade one ostaju žive i „sirove“"gotovo tokom ce$\log$ života, i jedan veliki balast za osobu koja nije u stanju da donese pravu odluku. Psihoterapeut Jeknić naglašava da: „Opažanje stvara utiske, a utisci produkuju misli koje prerastaju u razmišljanja. Bez redefinisanja utisaka, oni će doživot- 
no imati ulogu kao u momentu nastanka, iako su odavno pogrešni ili prevaziđeni. A tada postaju ozbiljan izvor napetosti i neravnoteže“ (Jeknić, 28).

\section{Ditrih Bonhoefer - žrtva grupe}

Ditrih Bonhoefer, protestantski pastor, koji se u vihoru Drugog svetskog rata vratio iz Amerike i došao u svoju rodnu Nemačku, pomagao je ljudima u razumevanju problematike koja im se događa. Izgleda da je on želeo da probudi ljude, ali su ga samo retki pojedinci shvatili ozbiljno. Ono što je on uradio jeste da je rekao jednu važnu rečenicu onima koji su vodili rat, nekrofilnima iz svog naroda, koja je ostala zapamćena i kao proročanstvo: „Vi ste mesečari i idete ka provaliji“ (Metaxas, 159). Ovo je njegova najsnažnija rečenica, kojom se jasno usprotivio pogrešnom razmišljanju grupe.

Erih From govori o tome da u vreme kada je došlo do pojave Hitlera, da su mnogi od njega očekivali dobrobit, da će on biti taj dobri otac, možda čak i spasitelj nacije i celog čovečanstva, dok su drugi koji su videli na kojim se metodama to zasniva, bili uplašeni i nisu imali hrabrosti da bilo šta kažu (Fromm, 53). Oni koji su nešto rekli, bili su uklonjeni.

Ditrih Bonhofer, Luteranski pastor, koga mnogi smatraju mučenikom i prorokom, je devetog aprila 1945 godine između 5 i 6 sati u jutro, u svojoj tridesetdevetoj godini života, nakon kratke molitve, hrabro pristupio vešalima završivši svoj život mučeničkom smrću, presudom Hitlerovih saradnika (Metaxas, 661667). Možda se pitamo zbog čega je to bilo potrebno, nekrofilnima, da osramote ovog čoveka, ali to je očigledno afekt i agresija, odgovor na sramoćenje koje su oni doživeli od njega, jer ga oni smatraju odgovornim za neuspeh grupe i neuspeh ,dobrog plana gospodarenja“.

\section{Put ka razgradnji straha - Klackalice ljudskih misli}

Misli koje se u čoveku događaju se nalaze na određenim klackalicama između potrebe da se podredi grupi ili da joj se ne podredi. Sećam se primera jednog čoveka koji je stalno ponavljao kako je u vojsci bio prihvaćen, kako ga je grupa na poslu prihvatila, kako je tu gde se sada nalazi ponovo prihvaćen, i gotovo je tim svojim ponavljanjem o prihvaćenosti, pokazivao koliko mu je zapravo važno da bude prihvaćen od strane grupe. Pošto mu je bilo veoma važno da uvek bude prihvaćen od grupe, prihvatio je pušenje i sve druge navike koje mu je grupa nametnula, jer su mu omogućile bolji status u grupi. Dakle, zbog straha pojedinac se 
voljno odriče svoje slobode donošenja odluka i podređuje sebe grupi, jer ne želi da bude izolovan i usamljen. Na ovaj način strah od izolacije na dugi rok postaje istovremeno i strah od grupe kojoj se podredio.

Upravo je to problematika koja je veoma interesantna, jer ukoliko se čovek odriče svoje slobode da razmišlja, da donosi odluke, on tako želi da pobegne od straha i stresa, time što će se prepustiti određenim zavisnostima. To može činiti i gledanjem TV-a, bavljenjem raznim stvarima na internetu, gledanjem raznih programa, materijala, sve čime čovek pokušava da zaokupi svoje misli kako bi ugasio vatru straha koja se u njemu pojavljuje.

\section{Klackalica praštanja i osvete}

Prava odluka bi bila praštanje, što je ustvari klackalica koja je veoma važna. Jedan biofil se odlučuje za praštanje, a jedan nekrofil se odlučuje za osvetu, odnosno da se osveti, da kazni. Nekrofil, nikada ne vidi ni mali deo udela svoje odgovornosti. On uvek zna ko je odgovoran, ali on nikako nikada nije u toj situaciji. On u svakom slučaju, kada razmišlja o praštanju, nema potrebu za praštanjem jer je on gotovo savršen i kod njega je sve u redu. Za njega u tim racionalnim, matematičkim odnosima, gde sve funkcioniše po principima dva plus dva je jednako četiri, gotovo je sve sasvim u redu. Sa druge strane on nema razvijene ,fajlove ljubavi“" u sebi za saosećanje u međuljudskim odnosima i u tom smislu je ostavljen da umesto praštanja bira osvetu.

Nikako ne treba prevideti ono što nam doktor Nidli predlaže: „Kada donosite odluku, razmišljajte analitički i bićete u stanju da se oslobodite procesa robovanja svojim emocionalnim razmišljanjima, koja vas drže u okovima nepoželjnog životnog stila“" (Nidli, 137).

From kaže da se nekrofili dele na one koji imaju silu i moć i spremni su da ubiju, i oni koji to nisu, koji nemaju tu moć (Fromm, 42). Dakle, osveta se pojavljuje kao klackalica između verbalne, neverbalne, parverbalne ili čak fizičke agresije i ukoliko ne postoji snaga, odnosno ukoliko je strah unutar nekrofilne osobe jak ona se plaši da krene u agresiju. Možda će se jednom nekada ohrabriti, ali u trenucima dok nije sigurna da li ima snagu i dovoljno agresije u sebi za osvetu, osećaće nemoć i upražnjavaće plač i suze. To je jedan narcistički model, (Fromm, 84-96) gde osoba počinje sebe da samosažaljeva i traži način od grupe, da iz pozicije žrtve utiče na grupu koja će omogućiti da pomogne ili nađe svog čoveka koji će izvršiti agresiju koju on nije u stanju da izvrši zbog svoje slabosti. To je neverovatan krug dešavanja koji se događa često unutar grupe. 
Jedna biofilna ličnost, za razliku od jedne nekrofilne ličnosti, je sklona praštanju i istovremeno pomaganju. Ono što biofil čini, jeste da na jedan sasvim drugačiji način „uništi“" nekrofilnu osobu, silom ljubavi Hristove , nebeske ljubavi, čime ona postaje sasvim drugačija. Ta ljubav stvara jednu potpuno novu plimu straha, u osobi koja izliva svoju agresiju, što je moj duživljaj koji me je veoma iznenadio. Izraženi nekrofil koji ima ogromne izlive verbalne agresije i sklonost ka fizičkoj agresiji, biva neutralisan kada se susretne sa osobom koja je biofilna i nije podložna strahu, jer apostol Jovan kaže da savršena nebeska ljubav, izgoni strah napolje (1. Jovanova poslanica 4, 16-20). Biofil prožet nebeskom ljubavlju, smirenošću i opuštenošću gotovo da je sušta suprotnost nekrofilu sa kojim se susreće, koji ima bujicu gnjeva i agresije, dok biofil ostaje potpuno opušten i miran. Biofil nije ciničan prema nekrofilu, već tom svojom opuštenošću, asertivnim govorom i osećanjima nebeske ljubavi, naglašava da ne vidi razloga za bilo kakvu nervozu i porukom da mu je sagovornik zapravo veoma draga osoba. Interesantno je da se tada doživljava jedno razoružanje nekrofila i njegove agresije. Događalo se tada da osoba koja ima izrazitu verbalnu i fizičku agresiju sedne, i moglo se paraverbalno jasno čuti koliko je u njoj prisutan strah.

\section{Bez prave ljubavi nije moguće postići unutrašnji mir}

Frojd naglašava važnost nagona na život - erosa i nagona na smrt tanatosa, koji predstavljaju nagone koji utiču na ljudski život, da se on stalno nalazi u dualizmu sukoba sa samim sobom, u pokušaju da se snađe na pravi način. Erih From snažno kritikuje Frojdovu tezu o erosu kao pokretačkoj sili života. On u svojoj knjizi „Umeće ljubavi“" sa velikim rezervama prihvata ovu Frojdovu ideju, jer From ne prihvata model grupe koja ne osporava orgijatičku strukturu intimnih odnosa. From želi da naglasi da to za njega nije prihvatljivo, jer on smatra da je najveća vrednost prava ljubav. Bez prave ljubavi, gotovo da intimnost dva bića može samo na trenutak da prebrodi strah, što znači da strah ostaje trajan. Iako su intimni odnosi, uzimanje droga, kao i druge zavisnosti, jedan model kojem se zbog sveprisutnog straha često pribegava u modernim orgijastičkim strukturama grupe, te zavisnosti samo na trenutak uklanjaju prisustvo straha a zatim strah postaje još snažnije prisutan. Iz tog razloga Erih From kaže da bez prave ljubavi, nije moguće postići spokoj niti mir u vlastitom biću (From, 19). 


\section{Unutrašnji mir se čuje kroz paraverbalnu komunikaciju}

Paraverbalna komunikacija je sastavni deo jedne poruke koju primalac poruke ne čuje preko sadržaja reči već preko boje i podrhtavanja glasa osobe koja šalje poruku (Ruckh, 19). Govornik govorom prezentuje svoje sposobnosti da jasno oslika određene stvari i pojmove. Njegovom porukom bivaju takođe predstavljeni njegovi stavovi, držanje i karakteristike njegove ličnosti. Primalac poruke odlučuje o verodostojnosti poruke na osnovu karaktera i društvenosti tj. druželjubivosti govornika, što pokreće simpatiju prema govorniku. Osvrtom na govornikovu ličnost u procesu procene verodostojnosti njegovog govora, kao i činjenicom koliko njegova boja glasa oslikava znanje struke i zaslužuje poverenje primaoca poruke, presudnu ulogu ima razvijena simpatija prema govorniku od strane primaoca poruke. Paraverbalna komunikacija prenosi osobine ličnosti, na osnovu kojih se govorniku može pripisati poverenje (Ruckh, 19-24).

Petar Jeknić navodi na svom youtube kanalu, u izlaganju o agresiji, da se granica između asertivnog i agresivnog ponašanja nalazi u osećanju, kao i da asertivnost nije moguća bez prisustva emocija. Asertivno ponašanje može biti i bez reči, ali u svakom slučaju podrazumeva unutrašnji mir (https://www.youtube. $\mathrm{com} /$ watch? $=$ Qfiv9PHCQBQ, pristup 12.5.2021).

Dubljom analizom, primetio sam da jedan nekrofil potpuno drugačije posmatra stvari, pokušavajući da govori asertivno, što znači da su njegove reči formulacija asertivnog, ali njegova neverbalna i paraverbalna komunikacije ne moraju biti u skladu sa onim što on izražava. To se nalazi u Svetom pismu u Korinćanima poslanici prvoj, trinaestoj glavi gde apostol Pavle kaže: „Ako imam sva znanja a ljubavi nemam, ništa sam“, (1. Korinćanima 13, 2), dok u prvom stihu on kaže: „onda sam kao zvono koje zvoni ili praporac koji zveči“. To je nešto što se u glasu osobe čuje. Ta boja glasa, drhtaj glasa, odražavaju da li osoba osećanjima doživljava ono što verbalno govori. Naravno da danas u savremenom svetu imamo jasna saznanja, pa ta paraverbalna komunikacija koja se zasniva na boji glasa i tonu glasa označava koliko je moguće prepoznati tu neravnotežu, nesklad između verbalne, neverbalne i paraverbalne komunikacije. Tačnije, kod jednog nekrofila će verbalno biti prisutna ljubaznost, ali će u neverbalnom, a najviše paraverbalnom smislu biti prisutna ta zveka koja označava da on ustvari sasvim drugačije razmišlja od onoga što pokazuje, što predstavlja kao klišee. On praktikuje te klišee jer je to danas aktuelno, on želi da bude potpuno u trendu, jer on želi da se nametne kao vođa i kao uzor. 


\section{Opuštenost je proces koji je moguć unutar biofilne grupe}

Ono što mogu da primetim je, da u dvorištu „Vladisavljević“ pčelarstva u Gospođincima, gde se nalazi nekoliko konja, protok vremena veoma pozitivno utiče na te životinje. Jedno ždrebe koje je sa četiri meseca došlo u to dvorište, kao novi konj u toj grupi bilo je veoma nemirno, uznemireno i plašljivo. Taj nemir je toliko bio snažan da nije bilo izgleda da će se situacija promeniti. Vrlo brzo, u periodu manjem od dva meseca, ovo se ždrebe potpuno promenilo, opustilo i prilagodilo opuštenom životu u okvirima mira koje ovi konji uživaju u tom dvorištu. Još drastičniji primer je jedna poni kobila koja je u starosti od četiri godine stigla u to dvorište. Kada je stigla bila je vrlo nepoverljiva prema ljudima, a istovremeno i prema drugim konjima. Bila je sklona da svakog, bez obzira da li je čovek ili neka druga životinja, udari ili ujede. Poređenja radi primetim da je za ovu kobilu od četiri godine trebalo potrebno godinu dana prilagođavanja. Sada je ona sasvim drugačija, prihvatila je ljude i više nema potrebu da bilo koga ujede ili udari, i te promene su neverovatne. To su promene koje zapravo treba da se dogode u svima nama kada osetimo sigurnost u okvirima grupe.

Dobročinstvo koje je pokazala Boni, Maltezer - maleni beli psić „Vladisavljević“" pčelarstva, je najbolji primer biofilnosti. Ona je nekoliko dana, više puta dnevno, svoju hranu iznosila iz dvorišta na ulicu, psu kojeg je udario automobil, sve dok se nije oporavio od teže povrede i otišao svojoj kući. Njena humanost, biofilnost i ,ljudskost“, pokrenule su osećanja ljudi koji su se pridružili pomaganju.

Od toga kakva je grupa zavisi, da li će rasti broj nekrofilnih ili biofilnih članova grupe. Od članova grupe zavisi u kom će se pravcu grupa razvijati. Biofilna grupa omogućava opuštenost pujedinaca unutar grupe. Postoje jasna saznanja da se nekrofilne osobe fokusiraju na mehaničke stvari i da nemaju osećanja. Oni su zainteresovani za zakone, pravila, za funkcionisanje i gotovo da ljude tretiraju kao stvari.

\section{Spasavajuća sila pojma smrti i postavljanje novih ciljeva}

Što se čovek više odvaja od sveta prirode, zbog narastajućeg straha naročito u gradskoj sredini, njegova potreba za izbegavanjem odvojenosti je sve veća (From, 19).

Psihoterapeut Jeknić nadodi da opažanje stvara utiske, a utisci produkuju misli koje prerastaju u razmišljanja. Bez redefinisanja utisaka, oni će doživot- 
no imati ulogu kao u momentu nastanka, iako su odavno pogrešni ili prevaziđeni (Jeknić, 28).

Psihoterapeut Irvin D. Yalom kaže da nas fizička smrt uništava, ali nas spasava ideja i pojam smrti. Upoznavanje smrti ima svoj koren u životu i uzrokuje radikalnu pozitivnu promenu u pogledima na perspektive vlastitog života (Yalom, 56-58). Upravo upoznavanje pojma smrti, ili naš lični „,bliski susret sa smrću“", pomaže nam da redefinišemo naše utiske i stavove. To će doprineti našoj novoj ličnoj podeli prioriteta vrednosti. Novi prioriteti i novi ciljevi postaju svrha našeg oslobađanja od nevažnog ili pogrešnog.

Viktor Frankl osnivač logoterapije, kao jedan od retkih logoraša iz logora Aušvic koji je preživeo, naglašava potrebu planiranja budućnosti usred najvećih pritisaka koje doživljavamo, postavljanjem ciljeva u budućnosti. Bez postavljanja ciljeva za vlastitu budućnost, logoraši su se gubitkom nade prepuštali apatiji. U stanju apatije odricali su se ono malo hrane koju su dobijali i menjali je za cigarete, kako bi pušenjem na kratko umirili svoj strah i preplavljenost beznađem, da bi ubrzo zatim umrli. Boraveći u logoru Frankl se gotovo neprekidno bavio svojim planovima budućeg života sa suprugom i porodicom kada se rat završi. Po završetku rata, baveći se logoterapijom, pomagao je mnogobrojnim osobama da iz vira svojih misli iskorače postavljanjem novih ličnih planova i ciljeva. Lični iskorak prema našim novim ciljevima je egzistencijalno važan (Frankl, 31-98).

\section{Nebeska ljubav - odgovor na probleme ljudske egzistencije}

Erih From navodi da izraziti nekrofil ne voli neizvesnost, voli jasnu sliku, crno - belo, i voli smrt jer je ona jedino izvesno buduće stanje za njega. Život je neizvesan i zato on svoj život strukturira striktnim pravilima i zakonima po već pomenutom principu „crno-belo“. From naglašava da je čist nekrofil duševno bolestan a da je čist biofil sveti čovek. On dodaje da su većina ljudi mešavina jednog i drugog (Fromm, 44, 53). Logičnim zaključivanjem može se naslutiti da je jedan prosečni biofil istovremeno i prosečan nekrofil, jer se nalazi na pola puta između jednog i drugog. Od svakoga od nas zavisi u kom smeru ćemo se mi, ali i drugi oko nas pod našim uticajem, nadalje razvijati i izgrađivati.

Erik From jasno naglašava da je ljubav odgovor i rešenje problema ljudske egzistencije (From, 15).

Sukob između dobra i zla, između Isusa Hrista i sotone, (Vajt, 383) u svojoj pozadini ima stres, strah, konflikte, sukobe i ratove. Kušajući Isusa, sotona Mu je pokazao „sva carstva ovog sveta i slavu njihovu“ a zatim Mu predložio: „Sve ovo 
daću tebi ako padneš i pokloniš mi se“ (Matej 4, 8. 9). Ovim predlogom je sotona razotkrio svoj plan ustoličavanja sebe na poziciji ,gospodara nad svim gospodarima“", gde bi Isus Hristos dobio mesto gospodara odmah ispod sotone i samim tim bio bi podređen sotoninoj vladavini kao njegov sluga. Naravno, Isus je pokazao da je „slobodan od sveta“ (Berđajev, 126) tj. slobodan od sotonske vladavine.(Matej 4, 10)

O Isusu Vajt piše: „On je istrajno obavljao svoju misiju milosti, iako je kao nagradu za dobro dobijao zlo, i mržnju za ljubav. Nikada nije odbio nikoga ko bi zatražio njegovu blagodat. Kao beskućnik i putnik, kome su poniženja i oskudica svakodnevno padali u deo, živeo je da služi nevoljnima, da olakša bedu bližnjima, da ih preklinje da prime dar života. Talasi milosti, koji su se odbijali od tih tvrdovratih srca, vraćali su se ponovo kao još snažnija plima saosećajne, bezgranične ljubavi“" (Vajt, 15).

Isus, starajući se za ljudska bića, pita: „Kakva je korist čoveku ako zadobije sav svet, a duši svojoj naudi“"? (Marko 8,36) Takođe, Isus je naznačio da On ne traži ,slave svoje“ a zatim razotktio sotoninu ličnost rečima: „ima koji traži (slavu) i sudi“ (Jovan 8. 50). Iznad najizraženijih nekrofila, duševno bolesnih i spremnih da ubiju (Fromm, 43-53), nalazi se „krvnik ljudski“" sotona (Jovan 8, 44). Iznad svih biofilnih svetih ljudi (Fromm, 53), nalazi se Isus Hristos (Jovan $3,16)$. Ovom analizom smo u stvari razotkrili ko predvodi Nekrofilnu a ko Biofilnu grupu.

Pre skoro dva veka, Vajt je napisala o sotoni: „On je proučio tajne laboratorije prirode i uložio sve svoje snage da zavlada elementima prirode... Dok se pred sinovima čovečijim pojavljuje kao veliki lekar, koji može da izleči sve njihove bolesti, on će izazivati bolesti i katastrofe... On ispunjava vazduh smrtonosnim uzročnicima bolesti i hiljade umiru za vreme epidemija. Ove pojave postajaće sve češće i sve ubitačnije“ (Vajt, 456-457).

Isusov biofilni put, uliva nadu, budi veru, veliča nebesku ljubav, otvara perspektive za nove vredne ciljeve, oslobađa straha i stresa, izobiluje unutrašnjim mirom i opuštenim životom. Apostoli Jovan i Marko nam jasno ukazuju ko je Isus: ,Jer Bog ne posla Sina svog na svet da sudi svetu, nego da se svet spase kroza Nj“ (Jovan 3, 17), ,Jer Sin čovečji nije došao da Mu služe nego da služi, i da da dušu svoju u otkup za mnoge“ (Marko 10. 45). Apostol Pavle nam jasno navodi neophodnost da se obučemo u Božje oružje (Efescima 6, 11-20), a Isus nam razotkriva put kojim treba da idemo, rečima: „Ja sam put i istina i život“" (Jovan 14, 6). „Bog će ožiljke prošlosti zauvek ukloniti iz naše duše. Povrede iz detinjstva će biti izlečene. Poražavajuži udarci, koji život iznenada raskomadaju, biće 
zaronjeni u bezgraničnom moru blagodati Hristove... U Hristovoj prisutnosti doživećemo večnu radost" (Finley \& Landless, 137).

Na kraju svoje knjige „Velika borba“, Vajt izražava svoju nadu u svetlu budućnost, koja ima oslonac u mnogobrojnim iskustvima pobede nebeske ljubavi: „Velika borba je završena... Sklad i radost ispunjavaju beskrajno delo stvaranja. Od onoga koji je sve stvorio teče život, i svetlost, i radost u sva prostranstva bezgraničnosti. Od najsitnije čestice do najvećeg sveta, sve stvoreno, živo i neživo, u svojoj nepomućenoj lepoti i savršenoj radosti, objavljuje da je Bog lju-

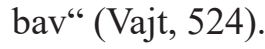

\section{Zaključak}

Stres i strahovi su prirodna reakcija organizma na nepredviđene situacije. Tek ukoliko organizam i posle dužeg perioda vremena nije u stanju da prebrodi ovakvo stanje napetosti, nastaju alarmni signali organizma. Nakon stresne situacije organizmu je potrebno vreme odmora i regeneracije. Problemi nastaju kada duže vreme ostanemo pod stresom u ,turbo modusu“ odbrane organizma, jer takvo stanje na duži rok može da naruši naše zdravlje.

Hormonalna neravnoteža može nastati usled loše ishrane, usled izloženosti toksinima, ili kao posledica dužoj izloženosti stresu ili strahu. Hormonalna neravnoteža uzrokuje slabljenje imunog sistema i otvara prostor za prisustvo trajnog hroničnog stresa ili straha.

Hronični stres, kao i klinički stres ostavlja tragove na psihičko zdravlje i ukoliko se ne poradi na razgradnji stresa, stvara podlogu za Burn-out i sekundarne oblike demencije.

Bolesti zavisnosti pogoduju bržem kretanju prema neuravnoteženim psihičkim stanjima i nikako nisu u mogućnosti da ovaj negativni tok zaustave. Kada govorimo o bolestima zavisnosti, mislimo prvenstveno na zavisnost lakim drogama: kafom, duvanom i alkoholom. Bolesti zavisnosti su još izraženije konzumiranjem raznoraznih opojnih jakih droga. Pored nabrojanih zavisnosti, sve više napreduje broj zavisnika od interneta, televizije, mobilnih telefona, kockanja, sportskih kladionica i drugog.

Da bi smo izbegli posledice trajnog straha i stresa, potrebno je da vežbamo sebe u procesu izgradnje ravnoteže između emocionalnih i racionalnih razmišljanja. Slušanjem religioznih propovedi, snaga vere nas može uspešno rasteretiti straha. To će nam pomoći da oprostimo i sebi i drugima, kao i da ožiljke vlastitog života konačno prihvatimo kao svoje. Nažalost, čovek je ipak spremni- 
ji da ide linijom manjeg otpora, kao i linijom osvete, i da tako sebe izloži bolestima zavisnosti.

Nove prespektive će se otvoriti pred nama ukoliko istrajemo u potpunom prihvatanju ožiljaka vlastitog života ispunjenog praštanjem. Jednostavno, kada se mi promenimo, otpustimo i pustimo, promeniće se i odnos drugih prema nama. Važno je naglasiti da je ova promena u stvari proces a ne trenutak, pa je podršha i ohrabrivanje prijatelja i rođaka gotovo neophodna.

Zdrava ishrana bez prisustva toksina i bogata medom, omogućiće nam hormonalnu ravnotežu kao i ravnotežu misli, emocionalnih i racionalnih. Jelovnik ispunjen jelima sa medom garantuje nam dobre šećere za naš um i stomak.

Biti pčelar, ili biti u društvu sa pčelarom i pčelama, znači ovladati prirodnim tehnikama opuštanja. Uz prisustvo pčelara apiterapeuta, ceo proces opuštanja od stresa i straha je mnogo uspešniji. Boravkom u prirodi sa pčelama, udisanjem pčelinjih aerosola $u$ apikomori, uzimanjem pčelinjih proizvoda i preparata jačamo imuni sistem i snagu vlastite volje na putu dobrih i zdravih odluka i navika koje nas čine opuštenima.

Higijena i nega tela domaćim apiterapeutskim sredstvima omogućava korisnicima trajno izbegavanje toksina u industrijskim proizvodima za negu tela. Sapuni, gelovi za tuširanje i šamponi, bogati pčelinjim proizvodima i etarskim uljima, omogućavaju put novih perspektiva, srećan i opušten život.

Magistar Stepanović, osnivač apiterapije u Srbiji i prvi predsednik udruženja API-BEO, kaže u svojoj knjizi: „Čovek koji živi po zakonima Prirode i po Prirodi se upravlja, životni vek produžava u odnosu na svog kolegu koji prebiva u gradskim četvrtima, prevozi se na posao automobilom, radi pod neonskim blještavim svetlom, prezalogaji komad jadne hrane sa sintetičkim mastima (obično je to sendvič sa margarinom i nekoliko narezaka salame) i flašom piva, vraća se prevozom u stan, gde ga čeka obično „ljuta“ (rakija), puna činija kuvanog pasulja sa kolenicom, par komada belog hleba, piće, kafa, kauč za odmaranje, fotelja ispred televizora. Takvima je vek trajanja određen između 37 i 59 godina. Ja sam za vreme od 15 godina ispratio na Jasikovo polje (mesno groblje u Grabovcu) njih 27 u toj dobi“ (Stepanović, 251).

Praktikovanje aktivnog odmora u okviru seoskog turizma, boravak u prirodi na otvorenom prostoru, na čistom vazduhu uz izlaganje zracima sunca, omogućava nam svežinu uma i tela. Boravak u prirodi , udisanje pčelinjih aerosola u apikomori, vožnja biciklom ili korišćenje usluga rekreativnog jahanja, su samo neke od važnih aktivnosti za dosezanje novih perspektiva života. Doživeti dodir prirode svim svojim čulima, kao na primer, osluškivati zvuke prirode: zuku pčela, cvr- 
kut ptica, šum povetarca, žubor vode, rzanje konja, kukurikanje petla, pomoći će nam da izađemo iz virtuelne realnosti i vratimo se sebi i prirodi.

Stalno prisustvo straha nagoni osobu da grupisanjem prevaziđe svoju usamljenost i strah. U uslovima savremene pandemije strahovi su osnova problema. Udruživanjem u grupu radi prevazilaženja ličnih strahova i usamljenosti, što je posledica života izvan prirode u velikim gradovima i u zatvorenom prostoru, pojedinac je sklon da donošenje ličnih odluka bazira na stavovima grupe. Radi straha i opstanka, kao i dobre pozicije u grupi, pojedinac ima sklonost da se prepustiti zavisnostima koje grupa upražnjava. Zavisnosti gospodare bićem putem straha, postepenim ukidanjem slobode razmišljanja, podređivanjem individue grupi kojom vlada sila straha, agresije i hijerarhija potčinjenosti jačem. Sve ovo je plodna podloga razvoju nekrofilnih profila ličnosti unutar grupe.

Borbe za dominaciju grupom proizvode dodatne strahove $\mathrm{u}$ pojedincima grupe. Agresija je stalno prisutna i aktivna jer konstantno dokazuje da je u pravu, traženjem krivca unutar grupe koji je „odgovoran za neuspehe grupe“, a sve to nastaje radi ostvarivanja lične dominacije grupom. „Odgovorni za neuspehe grupe“ bivaju kažnjeni što uzrokuje bujicu radosti zbog konačne osvete tj. agresije. Svaki pojedinac sklon nekrofilnim karakteristikama ličnosti bira osvetu umesto praštanja. Pojedinac je obično slabić ispunjen strahom koji nema hrabrosti da ispolji agresiju. On se grupom oseća jak, da ispolji svoju agresiju uvek iznova, jer jedna osveta samo na kratko nahrani biće unutrašnjim mirom.

Dok savremena pandemija jednima donosi strah, drugima donosi profit, jer strah je taj dobar novčić kojim se trguje. Strah utiče na berze u svetu, na pad i porast vrednosti kapitala, kao i na tok ljudskih misli. Pad vrednosti kapitala uzrokuje traume, a porast privremeno zadovoljstvo i sreću. Nekrofilni sejači straha ne žive bez straha. Na planeti bi ostale samo dve grupe ljudi, ukoliko bi se u svetu ukinule države i nacije. Svet bi se grupisao na biofilne i nekrofilne.

Na klackalici praštanja i osvete, prosečan nekrofil ne poznajući tehniku praštanja, uglavnom se prvo odlučuje na kratku verbalnu agresiju u vidu osvete. Ova verbalna agresija ga opušta na neko vreme ukoliko ne dobije nove uvrede kao odgovor, po pravilima reciprociteta. Pošto nema hrabrosti za ispoljavanje snažne agresije, on taloži događaje tj. pokretne slike loših iskustava, ponekad čak i godinama. Te neprerađene misli ostaju žive i ,sirove“ u njemu kao u trenutku događanja. On utiče na grupu iz uloge žrtve da izvrši agresiju zbog potrebe njegove osvete. Vremenom svaka agresija grupe može postati ,pravedna osveta i lek“ za njegovu dušu. U ime svog ,pravednog stava“, on počinje da podržava sve teža i teža nasilja nad pojedincima. Tako postaje bezosećajan, hladan, osvetoljubivi, iz- 
raženi nekrofil, koji živi u scenama svoje prošlosti koje pažljivo čuva u sebi, čime hrani sve svoje buduće agresije tj. nasilja. Sve agresije su u službi privremenog unutrašnjeg mira. Drugim rečima agresija privremeno opušta agresora. Ukoliko ne uspe da se profiliše u vođu osvetnika koji seje strah i dominira grupom, postoji mogućnost da će se jednom možda osvetiti sebi samoubistvom.

Strah doprinosi da par agresivnih nekrofilnih osoba mogu da drže veliku grupu pod svojom kontrolom. Događa se da agresor ,pomaže“ žrtvi verbalnom, psihičkom ili fizičkom agresijom, što žrtva svojim umom prihvata kao realnu pomoć.

Žrtve nasilja, kao i žrtve silovanja, iz meni dostupnih primera, često imaju izražen osećaj krivice i lične odgovornosti, smatrajući da su dale povod za agresiju nasilnika ili nasilnice. Nasilnici, su po pravilu nekrofilne ličnosti i nemaju gotovo nikada osećaj krivice.

Klackalice ljudskih misli nam jasno ukazuju na potrebu držanja ovih klackalica u ravnoteži. Lako može da se dogodi da iz te ravnoteže emocionalnih i racionalnih misli iskliznemo, što nije dobro. Klackalice naših misli treba dovesti u ravnotežu asertivnim govorom ispunjenim nebeskom ljubavlju. Asertivnim govorom ostvarujemo, sebi i drugima, prostor slobodan od agresije.

Bolji i kvalitetniji stil života omogućava edukacija i razvoj biofilnosti. Izborom biofilnih osoba za rad u ustanovama za kulturu, u zdravstvenim ustanovama i školama, omogućavamo celokupnom društvu sigurniji i opušteniji život.

Strahovi i stres, kada ih izgradnjom biofilnih karakteristika neutrališemo, postaju pokretačka sila motivisana nebrojenim pojavama života, mnogobrojnim mogućnostima novih životnih ciljeva u okvirima granica nebeske ljubavi.

Unutrašnji mir se čuje kroz paraverbalnu komunikaciju, a u toku vremena prerasta u opuštenost koja je moguća samo unutar biofilne grupe. Savršena ljubav Hristova omogućava nam slobodu od svih zavisnosti.

Ključ i rešenje problema čvorišta ljudskih misli se nalazi u potpunom poznavanju Isusa Hrista, najizraženijeg biofila svih vremena. Biofilnim osobama, koje slede Isusov put praštanja i nebeske ljubavi prema svim ljudskim bićima, omogućava im da na kraju svakog dana prerade i preslože svoje misli, oproste i oslobode se balasta negativnih scena dana, a zatim se opušteno i u miru dobro naspavaju. Dobar san vrši reparaciju i regeneraciju svih pređašnjih oštećenja ljudskog bića, pa se takve osobe bude odmorne $\mathrm{i}$ ispunjene novom životnom snagom.

Isus i naša lična najuža grupa naših najbližih, su naš oslonac koji nam u uslovima savremene pandemije omogućava mir, opuštenost i spokojstvo. Ovo najfinije stanje unutrašnjeg mira nam omogućava slobodu od svakog nezdravog straha, stresa ili napetosti. 
Ličnim poznavanjem Isusa Hrista čitanjem Evanđelja, vršimo razgradnju vlastitog prosečnog nekrofila na putu samopropadanja, što istovremeno upoznavanje prave nebeske ljubavi čini stvarnom pojavom. To pojedincu otvara put razumevanja i sprovođenja praštanja, kao i preslaganje vlastitih misli. Sve ovo vodi izgradnji novih perspektiva, kao i život na vedrijoj strani života.

Praktikovanjem najbolje meditacije tj. praktikovanjem moljenja Isusu Hristu, omogućavamo sebi postepenu izgradnju posvećenog života. From takvu osobu naziva izraženim biofilom.

Potpunim upoznavanjem Hrista, večne potpune istine i beskrajne sile nebeske ljubavi, postajemo deo grupe slobodnih od straha i slobodnih od verbalne, neverbalne, paraverbalne i fizičke agresije. Hristos je pokretačka i stvaralačka sila ljubavi nebrojenih pojava života u nama i oko nas. Sa Njim možemo uspešno ostvariti „reset“ naših misli i postići toliko neophodnu opuštenost u uslovima savremene pandemije.

\section{Literatura}

Amelung, E. \& Strohm, C. (1994). Dietrich Bonhoeffer Werke, Band 11, München: Gütersloher Verlagshaus / Keiser

Biblija - Sveto pismo (1993). Prevod: Đura Daničić i Vuk S. Karadžić, Biblijsko društvo, Beograd, Jugoslavija

Berđajev, N. (1991). O čovekovom ropstvu i slobodi, Novi Sad: Književna zajednica Novog Sada

Eder, E. (2009). Forschungsergebnisse zur Heilktaft der Apitherapie, Saarbrücken: VDM Verlag

Finley, M. \& Landless, P. Natürlich glücklich - Das Geheimnis ganzheitlicher Gesundheit, Wien: Top Life Wegweiser - Verlag

Freud, S. (2020). Vorlesungen zur Einführung in die Psychoanalyse, Hamburg: Nikol Verlagsgeselschaft

Frankl, V. (1994). Zašto se niste ubili: Traženje smisla življenja, Beograd: Žarko Albulj

From, E. (1993). Umeće ljubavi, Beograd: BIGZ

Fromm, E. (2020). Die Seele des menschen: Ihre Fähigkeit zum Guten und zum Bösen, München: dtv Verlagsgesellschaft

Grabe, M. (2012). Lebenskunst Vergeben, Korneuburg: Verlag der Francke \& CPI Moravia Books

Jeknić, P. (2020). Knjiga za svaki dan: Psihološka i psihoterapijska promišljanja i prak$s a$, Beograd: Centar za istraživanje religije

Kitwood, T. (2019). Demenz, Bern: Hogrefe Verlag

Krämer Eis, I. (2012). Die Apitherapie, Trier: WVT Wisenschaftlicher Verlag Trier

Metaxas, E. (2017). Bonhoeffer, Holzgerlingen: SCM - Verlag

Mötzing, G. \& Schwarz, S. (2010). Leitfaden Altenpflege, München: Urban \& Fischer

Münstedt, K. \& Hoffmann S. (2018). Binenprodukte in der Medicin, Aachen: Shaker Verlag 
Nadj Abonji, M. (2010). Tauben Fliegen auf, Salzburg und Wien: JUNG UND JUNG Nedoma, G. (2019). Das grosse Buch vom Oxymel, Vachendorf: Kampenwand Verlag Nidli, N. (2014). Izgubljena umetnost razmišljanja, Beograd: Preporod

Oppermann, J. (2018). Nützen sie die Schätze ihres Imkers, Bielefeld: LebensBaum Verlag Panagos, A. (2018). Die Macht der Hormone, München: Christian Verlag Pörner, G. (2015). Der Weg zur Gelassenheit, Berlin: Ullstein Buchverlag Ruckh, M. (2017). Kann paraverbale Kommunikation die Glaubwürdigkeit beeinflussen, Stuttgart: GRIN Verlag

Schröder, A. (2012). Gesuhdes aus Honig Pollen Propolis, Stuttgart: Ulmer EugenVerlag Stangaciu, S. (2015). Sanft heilen mit Honig, Propolis und Binenwachs, Stuttgart: Trias Verlag Stepanović, Ž. (2013). Darovi medonosne pčele, Beograd: Graficom - uno Šušnjić, Đ. (1989). Ribari ljudskih duša, Beograd: Čigoja

Terzin, T. (2010). Medonosna pčela: jevanđelje prirode, Beograd: Preporod Thuile, C. (2019). Bienen helfen heilen, Bozen: Athesia Verlag

Vajt, E. (2020). Velika Borba, Beograd: Preporod

Yalom, I. (2010). Existenzielle Psychotherapie, Köln: EHP - Verlag

\author{
Mirko Vladisavljević \\ Lucern, Švajcarska \\ vladisavljevic@gmx.ch
}

\title{
STRESS AND FEAR IN THE CONDITIONS OF THE CONTEMPORARY PANDEMICS
}

\begin{abstract}
Summary
Fears and stress are a knot of our thoughts that needs to be untied. When we succeed in that, stress and fear becomes the driving force of life motivated by countless phenomena of life, numerous possibilities of the new life goals within the limits of heavenly love. The perfect love of Christ "casts out fear" and allows us freedom from all addictions. Addictions are mastered by being through fear, by abolishing freedom of thought and freedom of existence, by subordinating the individual to a group ruled by the force of fear, aggression, and hierarchy subordination to the stronger. Aggression is constantly active because it constantly proves that it is right, by looking for the culprit in order to achieve some personal domination. By fully knowing Christ, eternal truths and the infinite power of heavenly love, we become part of a group of free people from fear and free from verbal, nonverbal, paraverbal and physical aggression. It is Christ one who is the driving and creative force of love of the innumerable phenomena of life in and around us. With him we can successfully "reset" our thoughts and achieve the much-needed relaxation in time modern pandemics.
\end{abstract}

Keywords: stress, fear, addiction, aggression, group, Christ, love, life, relaxation 